\title{
Mayflies (Ephemeroptera) and Their Contributions to Ecosystem Services
}

\author{
Luke M. Jacobus ${ }^{1, *(\mathbb{D})}$, Craig R. Macadam ${ }^{2}$ and Michel Sartori ${ }^{3,4}$ \\ 1 Division of Science, Indiana University Purdue University Columbus, 4601 Central Ave., \\ Columbus, IN 47203, USA \\ 2 Buglife-The Invertebrate Conservation Trust, Balallan House, 24 Allan Park, Stirling, \\ Scotland FK8 2QG, UK; craig.macadam@buglife.org.uk \\ 3 Musée cantonal de zoologie, Palais de Rumine, Place de la Riponne 6, CH-1005 Lausanne, Switzerland; \\ michel.sartori@vd.ch \\ 4 Department of Ecology and Evolution, University of Lausanne, Biophore, CH-1015 Lausanne, Switzerland; \\ michel.sartori@unil.ch \\ * Correspondence: lukemjacobus@alumni.purdue.edu; Tel.: +1-812-348-7283
}

Received: 22 January 2019; Accepted: 6 June 2019; Published: 14 June 2019

\begin{abstract}
This work is intended as a general and concise overview of Ephemeroptera biology, diversity, and services provided to humans and other parts of our global array of freshwater and terrestrial ecosystems. The Ephemeroptera, or mayflies, are a small but diverse order of amphinotic insects associated with liquid freshwater worldwide. They are nearly cosmopolitan, except for Antarctica and some very remote islands. The existence of the subimago stage is unique among extant insects. Though the winged stages do not have functional mouthparts or digestive systems, the larval, or nymphal, stages have a variety of feeding approaches-including, but not limited to, collector-gatherers, filterers, scrapers, and active predators-with each supported by a diversity of morphological and behavioral adaptations. Mayflies provide direct and indirect services to humans and other parts of both freshwater and terrestrial ecosystems. In terms of cultural services, they have provided inspiration to musicians, poets, and other writers, as well as being the namesakes of various water- and aircraft. They are commemorated by festivals worldwide. Mayflies are especially important to fishing. Mayflies contribute to the provisioning services of ecosystems in that they are utilized as food by human cultures worldwide (having one of the highest protein contents of any edible insect), as laboratory organisms, and as a potential source of antitumor molecules. They provide regulatory services through their cleaning of freshwater. They provide many essential supporting services for ecosystems such as bioturbation, bioirrigation, decomposition, nutrition for many kinds of non-human animals, nutrient cycling and spiraling in freshwaters, nutrient cycling between aquatic and terrestrial systems, habitat for other organisms, and serving as indicators of ecosystem health. About $20 \%$ of mayfly species worldwide might have a threatened conservation status due to influences from pollution, invasive alien species, habitat loss and degradation, and climate change. Even mitigation of negative influences has benefits and tradeoffs, as, in several cases, sustainable energy production negatively impacts mayflies.
\end{abstract}

Keywords: aquatic insects; diversity; adaptations; ecology; freshwater systems; terrestrial systems

\section{Introduction}

Our contribution to the Diversity and Ecosystem Services special issue of this journal focuses on the amphinotic insect order Ephemeroptera and the varying — but specific - roles these diverse organisms play in providing direct and indirect services to humans and other parts of our global 
array of freshwater and terrestrial ecosystems. This work is intended as a concise overview that provides general examples, illustrations, and context. It is not exhaustive. We attempted to balance communicating the breadth of the extensive information available with providing a concise and readable summary.

Few other groups of insects may have such a variety of common names as Ephemeroptera. Though Ephemeroptera are generally referred to as mayflies, they sometimes are called dayflies, shadflies, or even fishflies. The names of particular species can be vividly descriptive [1], such as the Yellow may dun (Heptagenia sulphurea (Müller) (Heptageniidae)), or March brown (Rhithrogena germanica Eaton (Heptageniidae) and Maccaffertium vicarium (Walker) (Heptageniidae)), or of more obscure origin such as Jenny spinner (Paraleptophlebia mollis (Eaton) (Leptophlebiidae)) or Drake mackerel (Ephemera vulgata Linnaeus (Ephemeridae)).

As scientific pursuits grow in complexity and necessarily narrow in focus, we risk the danger of losing sight of the interconnections and broader implications of individual components of ecosystems. Mayflies spend the majority of their lives under water, out of human sight and mind. Thus, they are an ecosystem component that easily eludes the continued attention of those not a part of the "guilds" (borrowing a term from Niko Tinbergen's Foreword to Dethier's To Know a Fly [2], and later used here in another context) of aquatic biologists and others who spend time with them daily.

Mayflies are known best in popular culture for their short-lived adults, which may survive for only minutes [3]. They also are well-known for their mass emergences, which can cover areas tens or hundreds of square kilometers in size with swarms estimated to be 125-250 m thick; these are significant enough to be detected and tracked en masse on weather radar $[4,5]$. To the angler and ecologist [6] they are known for serving as patterns for imitations [7] and for being indicators of environmental quality [8], respectively. However, mayflies also warrant special attention for the many other important services they provide as constituents of freshwater and terrestrial ecosystems.

\section{Biological Attributes of Mayflies}

The provision of ecosystem services by mayflies is both enabled and constrained by the biological attributes of the organisms themselves.

\subsection{Life Cycle and General Biology}

Mayflies are unique among extant insects by having a subimago stage in their metamorphic cycle (Figure 1a). The subimago is an active and mobile stage that occurs between the ultimate larval instar and the mature adult stage, or imago, when present in the life cycle [9]; however, in a few rare cases, the subimago is the terminal stage in females (e.g., Dolania Edmunds \& Traver (Behningiidae) [10], Prosopistoma Latreille (Prosopistomatidae) [11,12], or even in both sexes (e.g., some Palingeniidae [13]). This is a remarkable example of reproductive diversity, in that different stages of the order may be the mature stage of a particular species. In general, the subimago represents the transition from the aquatic to terrestrial parts of the mayfly species' lifecycle, sometimes with very large numbers of individuals emerging simultaneously from the water (e.g., [14]). The subimago molts to the imago stage while resting on riparian vegetation or, rarely, in the air, mid-flight [15]. Subimagoes and imagoes (Figure 1b) are notoriously short-lived and therefore have a narrow window of time during which they provide ecosystem services. With non-functional mouthparts and digestive systems, the imago stage (and also to a certain extent the subimago) is specialized for dispersal and reproduction. Alate individuals usually have two pairs of wings, with the hind wings being smaller than the forewings (Figure 1); a few taxa have only the forewings. Alate stages (Figure 1) have two or three terminal filaments of varying relative lengths, depending on the taxon in question.

Mayfly species engage in both sexual and parthenogenetic (asexual) reproductive strategies [16]. Most species lay eggs under the water's surface, though a very few are ovoviviparous (e.g., Callibaetis Eaton (Baetidae) [17], Cloeon Leach (Baetidae) [18]). Most species are probably univoltine in temperate 
regions, though many may have multiple generations per year, and a few may require two or three years to complete their life cycle.

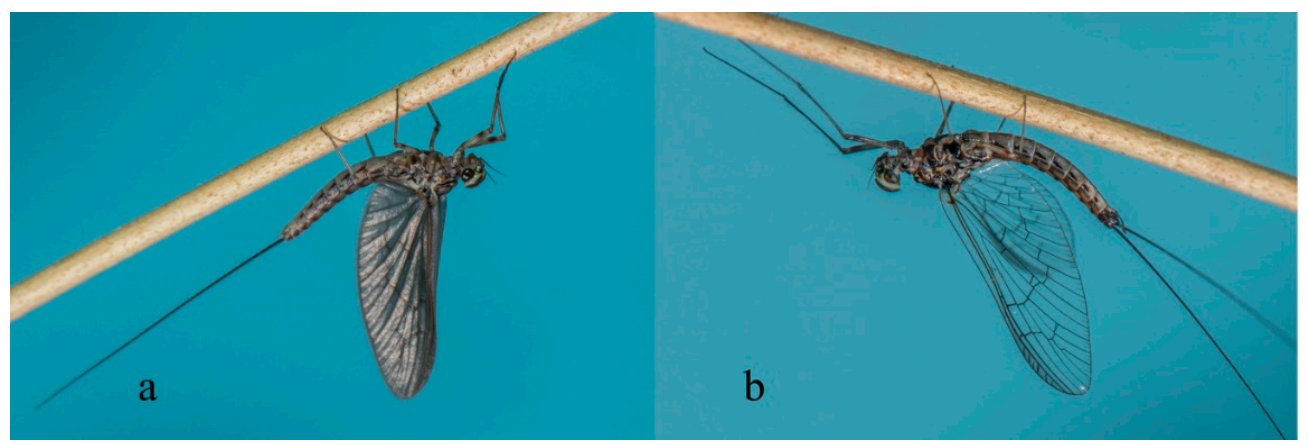

Figure 1. Cloeodes penai (Morihara \& Edmunds) (Baetidae, Brazil) male subimago (a) and imago (b). Photograph courtesy of Frederico Salles.

The strictly aquatic larvae, also called nymphs, are comprised of several instars. The number of instars that occur during an individual's life depends primarily on food resources [19] and water temperature (e.g., [20]). The larvae are common constituents of most freshwater biotopes, both lotic and lentic, and in some cases can tolerate brackish water at least temporarily [21,22]. The larvae are found on or in almost all submerged substrates. Their near ubiquity in freshwaters indicates how widely mayflies are contributing to ecosystem services. Their absence can be an indicator of problems in particular environments (see further discussion below). Fortunately, mayfly larvae are easily distinguished from other aquatic insects. The larvae of mayflies usually have three terminal filaments (e.g., Figures 2-4), though some have two. Larvae have prominent forewing pads (Figure 3); hindwing pads are much smaller, sometimes being vestigial, or absent. Larvae have ten abdominal segments, with pairs of articulated gills on at most segments one through seven (Figure 3). The body lengths (excluding terminal filaments) of the vast majority of species fall between about 2 to $30 \mathrm{~mm}$.

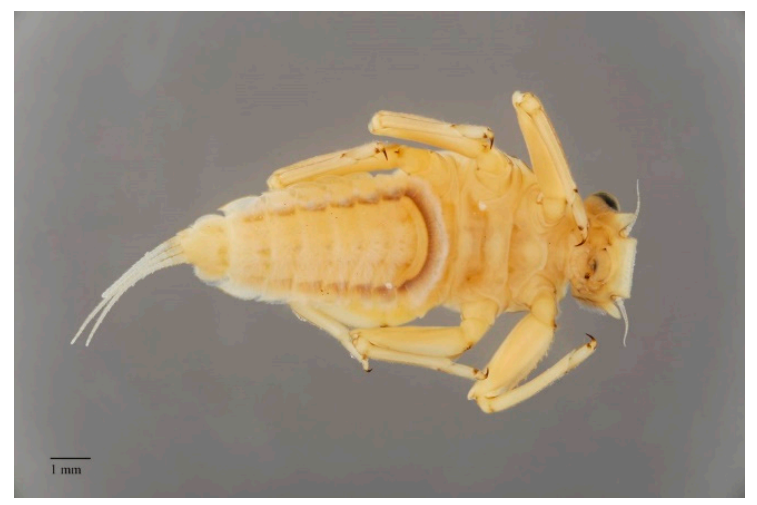

Figure 2. Dodds' spiny crawler mayfly, Drunella doddsii (Needham) (Ephemerellidae, USA) in ventral view; abdominal sternites with rows of setae as a friction disk to adhere to the substrate in a fast flowing stream.

The larvae of mayflies can be assigned to a variety of feeding groups, or guilds, in aquatic systems. These feeding groups usually correspond to particular ecosystem services outlined elsewhere in this paper. A variety of morphological adaptations enable various behaviors and the penetration of specific microhabitats where services are carried out. Most taxa are collector-gatherers and scrapers, usually feeding on detritus and periphyton, with bacterial ingestion perhaps also playing an important role in their nutrition (e.g., [23]). These functions are facilitated by specialized mouthparts. Scrapers, for example, often have bladelike mandibles. In swift-water habitats, a variety of abdominal adaptations, 
such as friction disks formed by setae (e.g., some Drunella Needham (Ephemerellidae), Figure 2) and gills (e.g., Rhithrogena Eaton (Heptageniidae), Figure 4), enable individuals to maintain their purchase while feeding [24]. These collector-gatherer and scraper taxa are generally clinging, sprawling, and swimming in habit, with these tendencies facilitated by the morphology of their claws and orientation of legs, generally flattened bodies (Figure 3), or streamlined bodies, respectively.

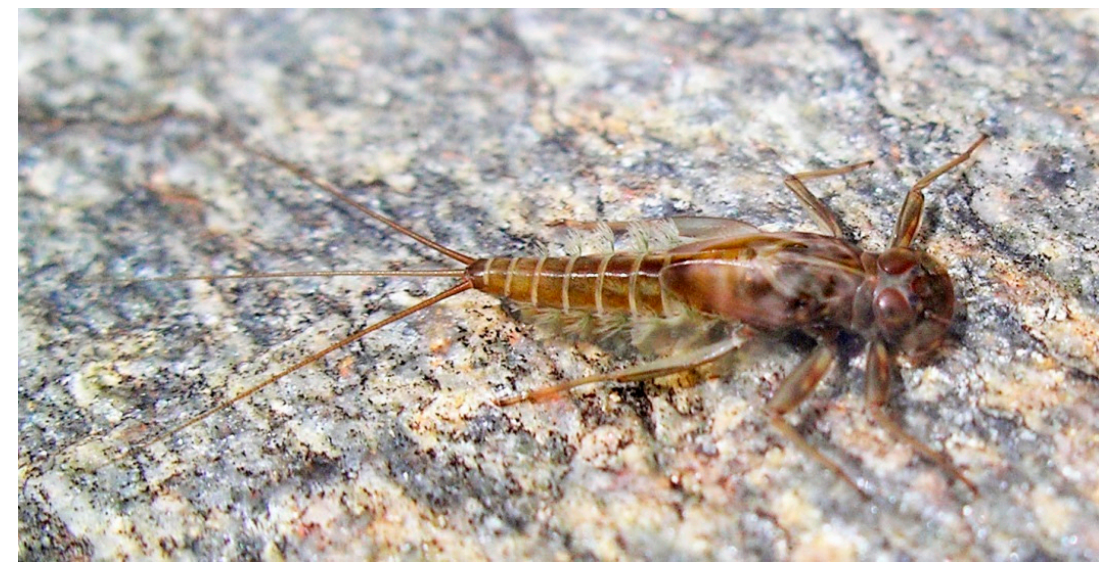

Figure 3. Rhithrogena loyolaea Navás (Heptageniidae, Switzerland) in dorsolateral view in its natural habitat; the flattened body, strong legs and first pair of gills functioning as a suction disk allow this species to withstand very strong current speed. Photograph courtesy of Laurent Vuataz.

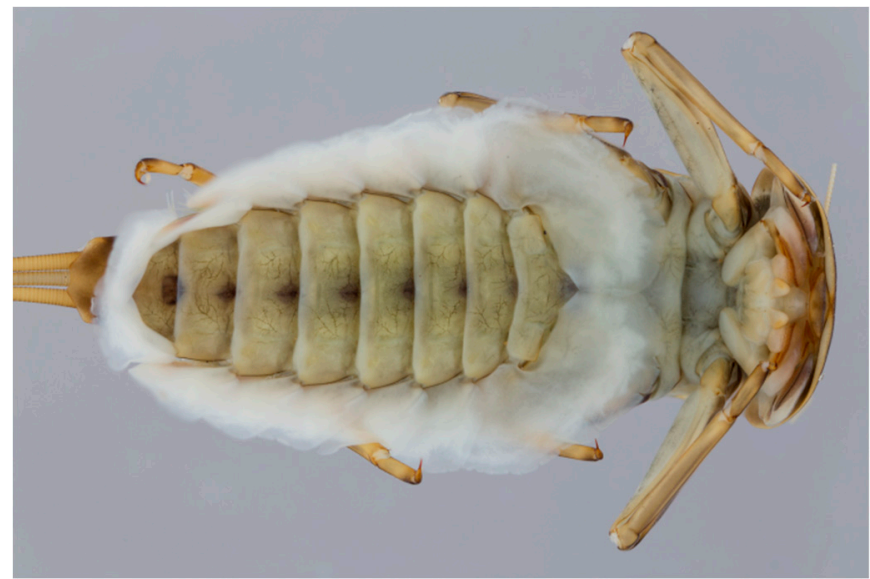

Figure 4. Rhithrogena loyolaea Navás (Heptageniidae, Switzerland) in ventral view to show the gills adapted to function as a suction disk.

Several taxa, such as species of the genera Coloburiscus Eaton (Coloburiscidae), Isonychia Eaton (Isonychiidae), and Oligoneuria Pictet (Oligoneuriidae) (Figure 5) are filter feeders and may use rows of setae on their forelegs to capture particulate matter passively; others, such as Arthroplea Bengtsson (Heptageniidae) may use specialized maxillary palps (Figure 6) to create vortices that actively concentrate particles from the water column [25], while others yet, such as Ametropus Albarda (Ametropodidae), may use the forelegs to create such a vortex [26]. Burrowing mayflies have legs and tusks modified for digging (Figures 7 and 8) in a variety of benthic habitats including clay banks and heavy muck, and they use their gills to help move water through their burrows in order to collect food items [27]. Very few of these burrowing taxa, such as Povilla adusta Navás (Polymitarcyidae), bore into rotting wood, sometimes causing problems with human structures submerged in water [28]. Other mayfly taxa live and forage on or among sediments; these taxa often have operculate gills (Figure 9) that protect subjacent gills (e.g., most Caenidae and some Ephemerellidae) or modified abdominal 
segments that protect the gills (e.g., Hyrtanella Allen \& Edmunds (Ephemerellidae), Machadorythus Demoulin (Machadorythidae) Figure 10).

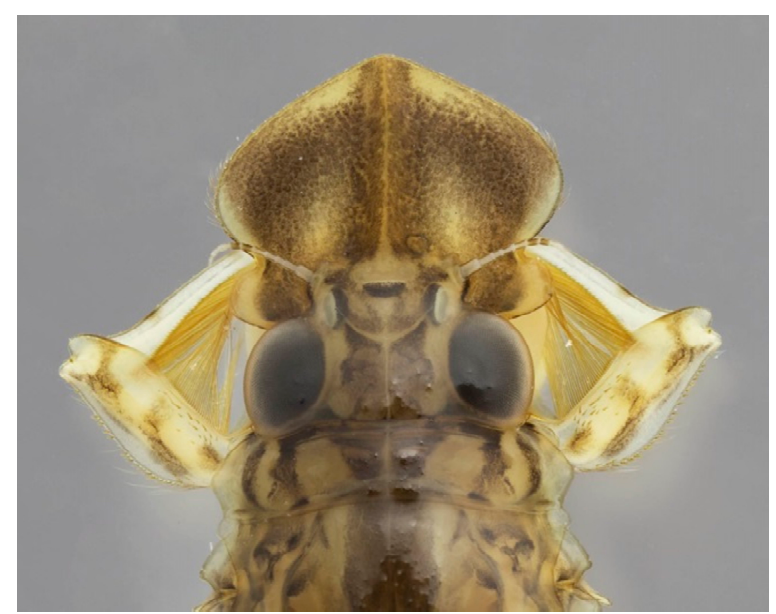

Figure 5. Oligoneuria mitra Salles, Soares, Massariol \& Faria (Oligoneuriidae, Brazil) detail of head and prothorax in dorsal view; the first pair of legs equipped with filtering setae.

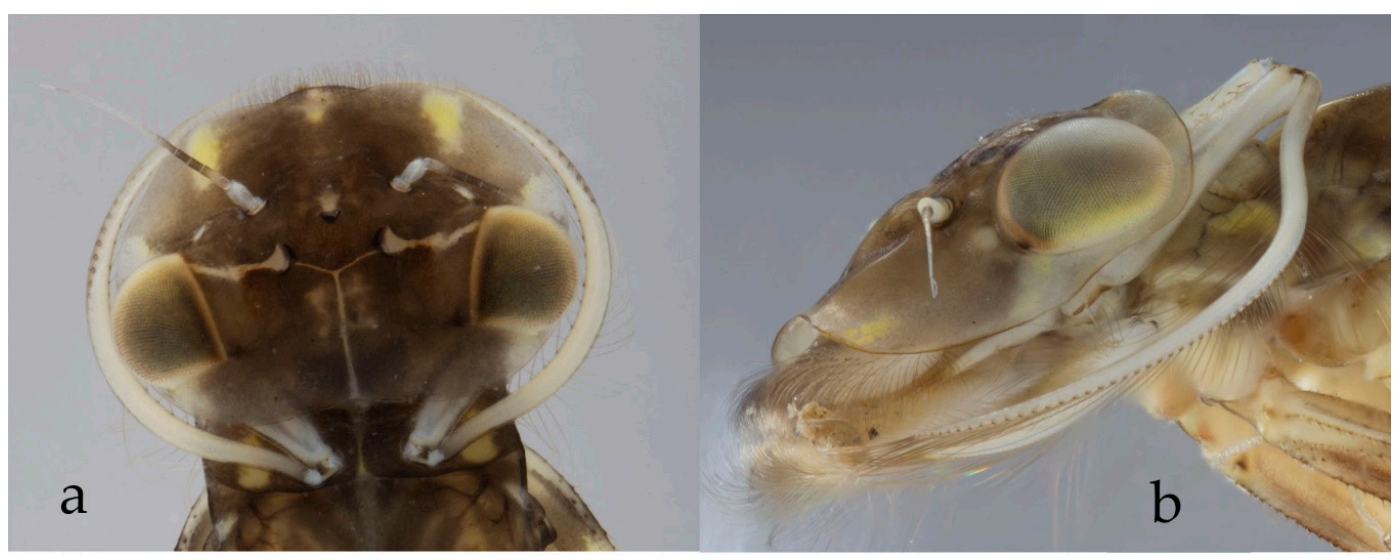

Figure 6. Arthroplea congener Bengtsson (Heptageniidae, Switzerland) in dorsal (a), and lateral (b) view: head, with maxillary palps clearly visible on the sides that are used to create filtering vortices.

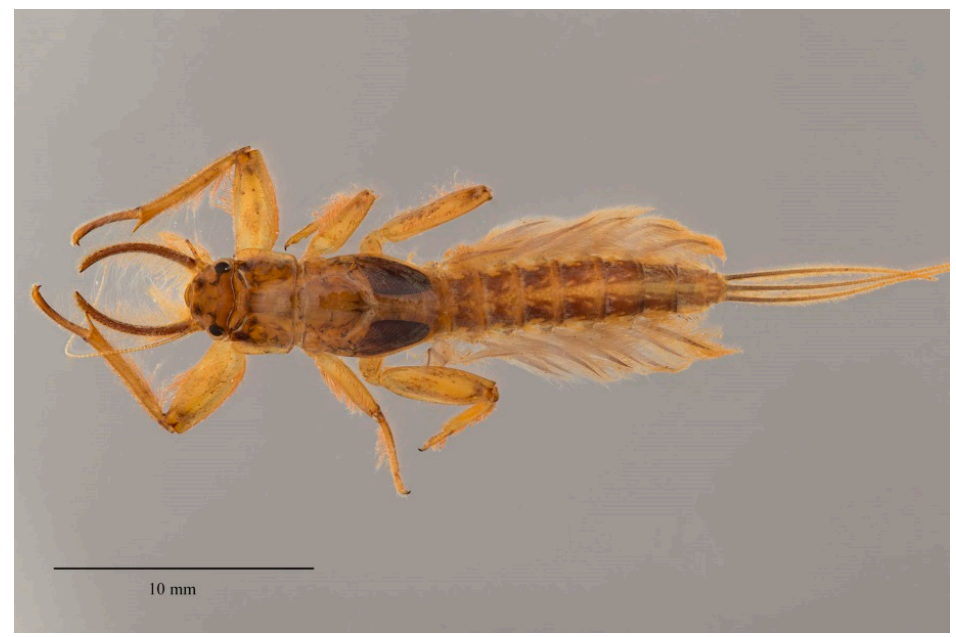

Figure 7. Ultimate larval instar of Polyplocia campylociella Ulmer (Euthyplociidae, Borneo) in dorsal view; a semi-burrower that uses its long mandibular tusks to dig soft substrate under cobble. 


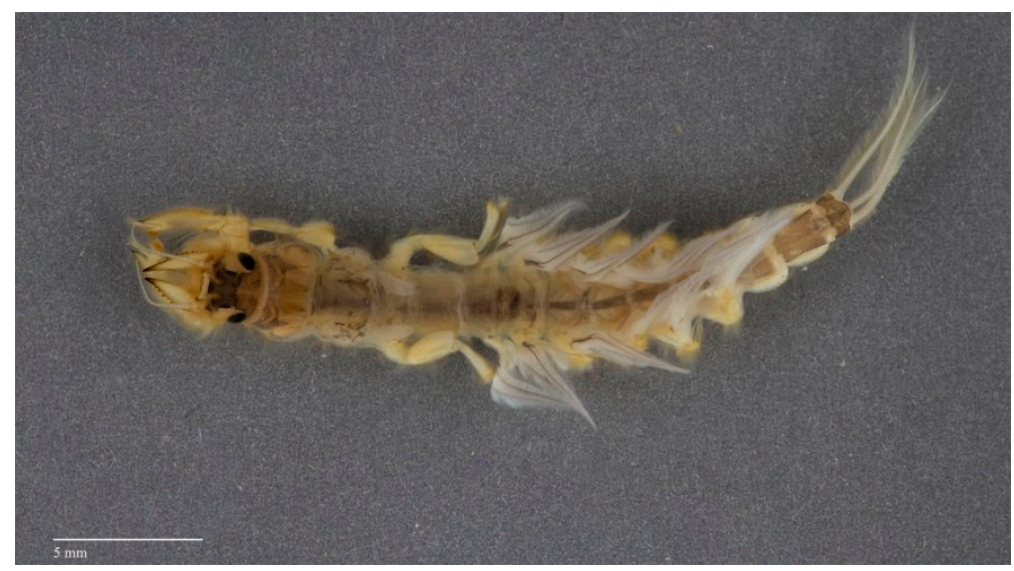

Figure 8. Larva of Cheirogenesia edmundsi Sartori \& Elouard (Palingeniidae, Madagascar) in dorsal view; a burrower which digs into hard substrates, such as clay.

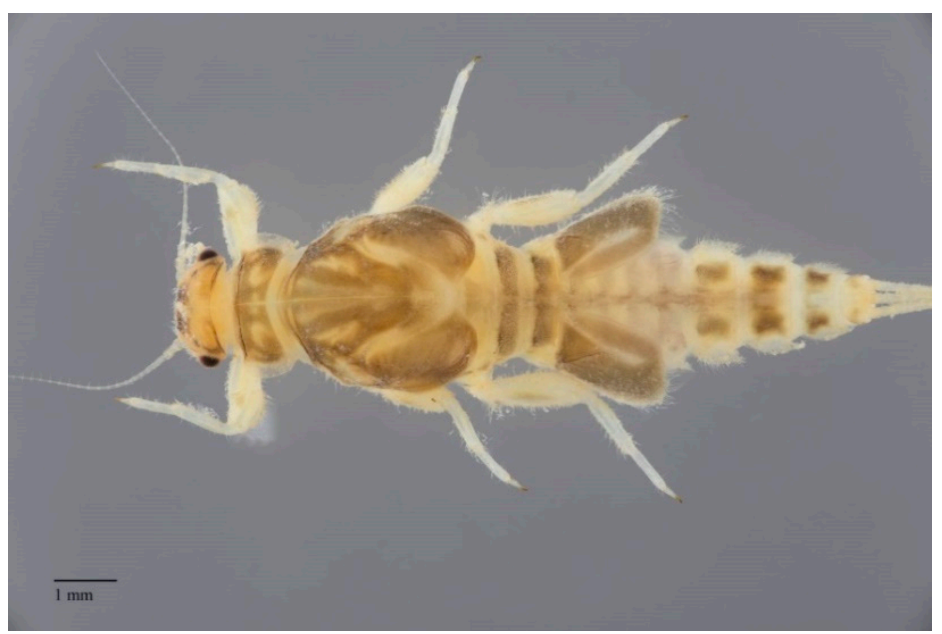

Figure 9. Caenis luctuosa (Burmeister) (Caenidae, Switzerland) in dorsal view; the second pair of gills is operculate and protects the delicate subjacent ones.

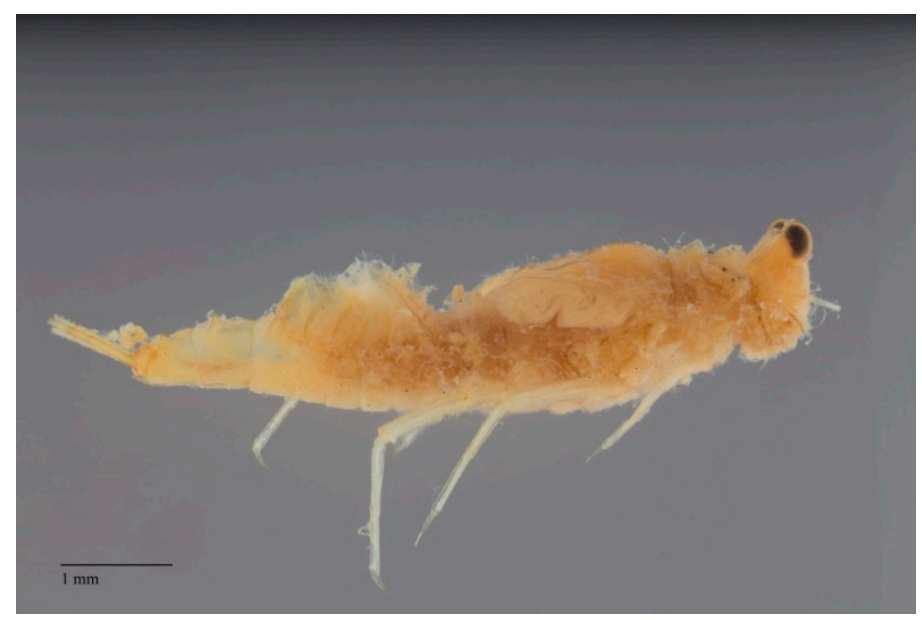

Figure 10. Machadorythus maculatus (Kimmins) (Machadorythidae, Ivory Coast) in lateral view; with middle abdominal segments modified to form a gills basket.

Other taxa are predators (Figure 11), usually feeding on Chironomidae (Diptera) larvae or other mayflies (e.g., [29]). A few taxa may be leaf and vegetation shredders [30] (Figure 12). Rarely, mayflies are considered parasitic, such as the case of Symbiocloeon Müller-Liebenau (Baetidae) on mussels. 
However, this relationship actually is commensal in nature [31]. The association of mayflies with mussels in this way is a remarkable parallel coincidence when one considers the early developmental and dispersal biology of mussels, which involves attachment of larvae (glochidia) to fish gills.

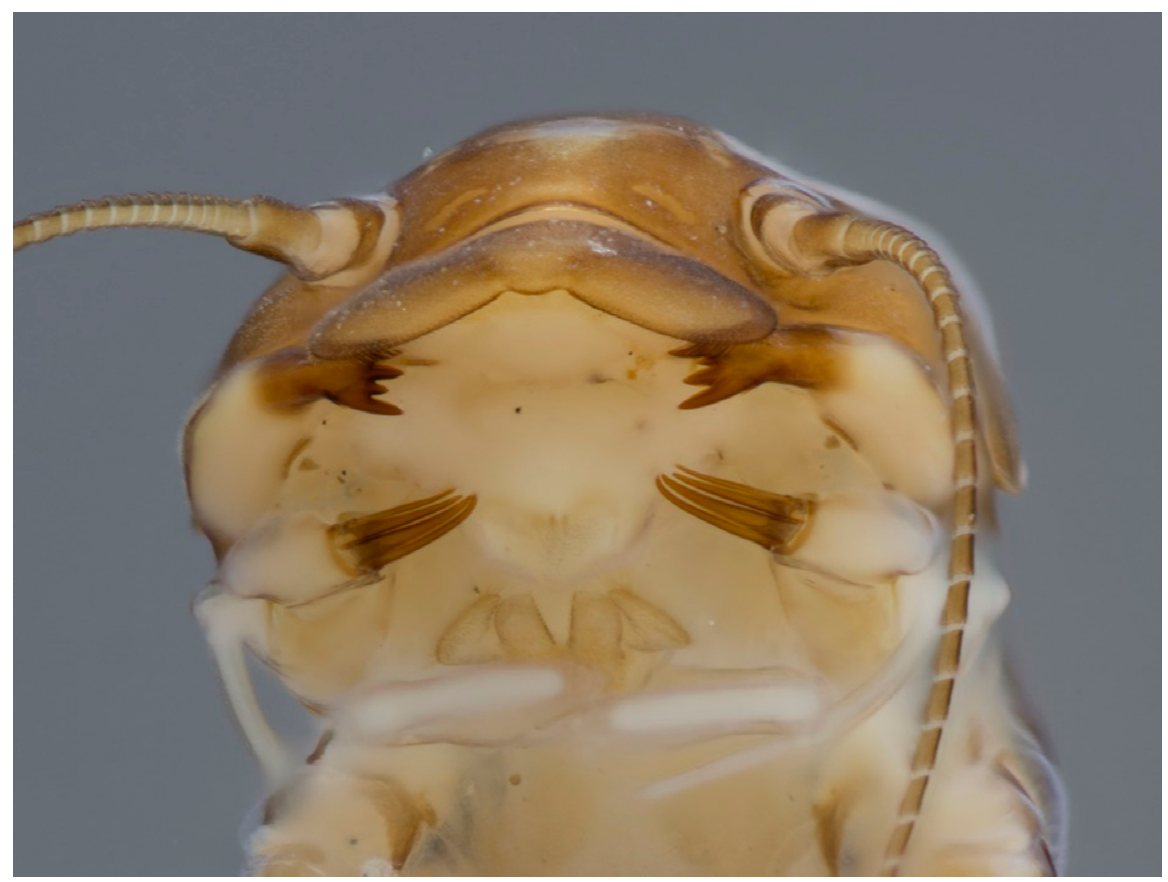

Figure 11. Guloptiloides gargantua Gattolliat \& Sartori (Baetidae, Madagascar) details of the head in ventral view; mandibles and maxillae blade-like to prey mainly on other baetid larvae.

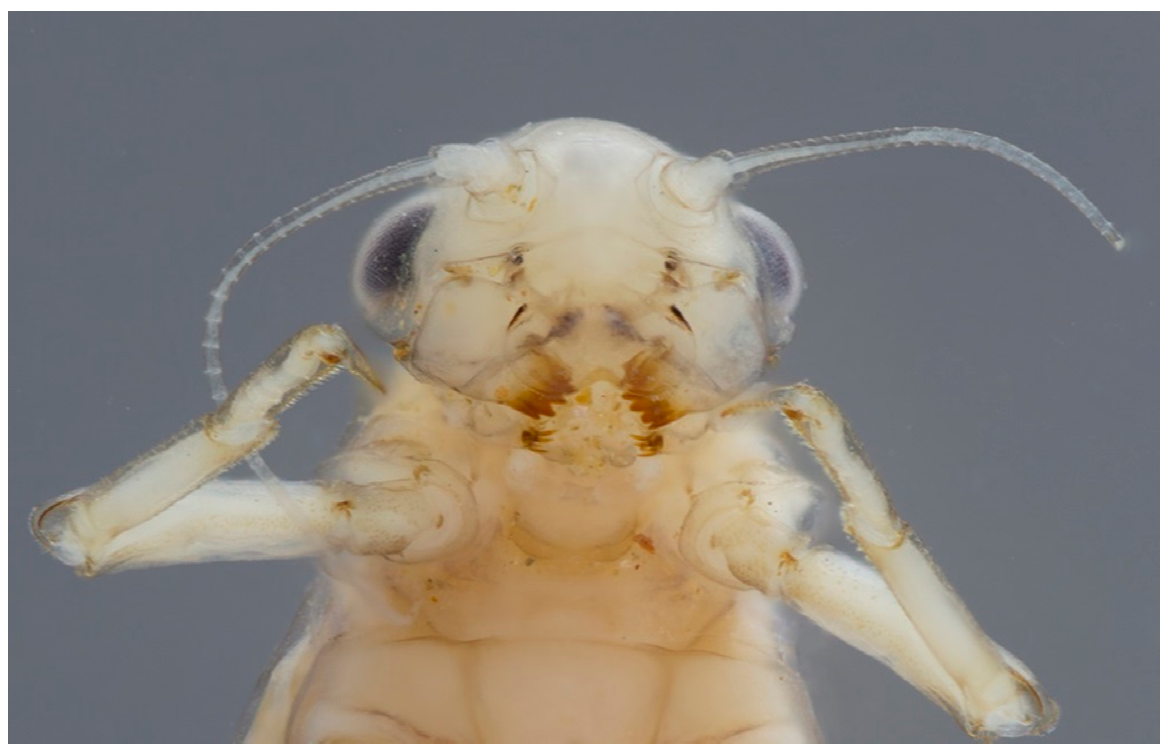

Figure 12. Edmulmeatus grandis Lugo-Ortiz \& McCafferty (Baetidae, Madagascar) detail of head in ventral view; mandibles are cricket-like; this species shreds exclusively on Hydrostachys Thouars (Cornales: Hydrostachyaceae) aquatic plants and is completely green when alive.

In many cases, the feeding preferences and general habits of mayfly taxa are assumed based on their morphologies [30] and have not been observed directly. Expanding our knowledge of the microhabitats, movement, and feeding behaviors of mayflies will help us also to expand our knowledge of the precise ecosystem services provided by mayflies. 


\subsection{Global Diversity and Distribution}

Ephemeroptera constitutes a small order of amphinotic insects associated with freshwaters worldwide, having fewer than 3700 species currently recognized. With origins more than 300 million years ago [32], it is one of the oldest groups of extant insects and has a relatively long history of contributing to planetary function.

The monophyly of Ephemeroptera is well-established, but its relationship with Odonata and Neoptera is not yet consistently resolved (see e.g., [33-35]). The phylogenetic relationships among mayflies themselves also remain unclear and partially unresolved. Resolution of deep levels of mayfly phylogeny remains elusive, confounding efforts to form consistent hypotheses about the groups' adaptive radiations and the general evolution of ecological roles and associated ecosystem services. Based on molecular data, however, the monotypic family Siphluriscidae is hypothesized to be basal and the sister-group to all others [36], which is consistent with its many plesiomorphic features. Some families cluster together with confidence, such as those included in Ephemerelloidea, Caenoidea, and Fossoriae. Relationships within these broad groupings are not well understood at the moment, however. Additional molecular, morphological, and behavioral data may shed light on some of these longstanding problems.

Mayflies can be found in freshwater ecosystems distributed throughout the world. As stated previously, their near ubiquity is evidence of their wide contribution of ecosystem services, even though they are a relatively small order. They are absent only from Antarctica and some remote ocean islands, such as the Tristan da Cunha archipelago [37] or the Falkland/Malvinas Islands [38]. Some arctic and subarctic islands have very low diversity, such as Greenland and Iceland, which are inhabited by a single species each $[39,40]$.

It has been generally hypothesized that mayflies are poor dispersers, due to their low vagility and short alate lifespans previously discussed. Recent studies, however, found that some oceanic and volcanic islands, such as Macaronesia [41,42] and the West Indies [43], have been colonized with subsequent in situ radiation. Continental islands, such as those that broke off of Gondwana, have unique lineages; examples of this kind of island include Madagascar, New Caledonia, and Seychelles.

About 20 species generally present Holarctic distributions, either Circumarctic (e.g., Nixe joernensis (Bengtsson) (Heptageniidae), the Eurasian flat-headed mayfly) or Transpacific (e.g., Baetis bicaudatus Dodds (Baetidae), Dodds' small minnow mayfly), whereas more than 40 species have a Pan-American distribution as a result of the Great American Interchange [44]. Virtually all species from the Oriental, Afrotropical, Australasian, and Pacific Realms are endemic. The highest generic endemism is found in the Pacific, Afrotropical, and Australasian Realms.

The highest mayfly diversity is found in the Neotropics with almost 900 described species, followed by the Palaearctic (830), Nearctic and Oriental (610 and 620 respectively), Afrotropical (440) Australasian (250), and Pacific (48) (data updated from [45]). In general, diversity is greatest in the intertropical region and decreases towards the poles. Diversity also generally decreases with an increase in altitude.

Our knowledge about the diversity of mayflies worldwide is still increasing year after year. Since the last assessment [45] (about four years ago at the time of this writing), more than 300 new species have been described, and many still await description, especially in the tropics.

The composition of Ephemeroptera families and genera have changed greatly during the last 25 years, mainly because of the gathering of species into a more phylogenetic system. These narrower concepts of genera and families better reflect the diversity of the order in terms of how form, function, and ecosystem services align. Currently, mayfly species are spread among about 40 families (depending on the classification system used) and more than 460 genera. A few families are monogeneric and monospecific, namely Austremerellidae (Australia), Machadorythidae (West Africa), Rallidentidae and Siphlaenigmatidae (New Zealand), and Siphluriscidae (China). More than half of the families contain fewer than 20 species. The three richest families-Baetidae (110 genera, 1070 species), Heptageniidae $(37,606)$, and Leptophlebiidae $(147,718)$ —encompass two-thirds of all known species. On the generic 
level, four genera possess more than 100 species each: Caenis Stephens (Caenidae) with 164 species, Baetis Leach (Baetidae) with 158 species, Rhithrogena (Heptageniidae) with 155 species, and Labiobaetis Novikova \& Kluge (Baetidae) with 104 species. No genus has a true cosmopolitan distribution. Among the most widespread genera, Caenis and Baetis are mentioned from the Australasian Realm by single and dubious records, whereas Choroterpes Eaton (Leptophlebiidae) reaches only Sulawesi in Australasia [46]. Labiobaetis is only absent from the Neotropics, as was Cloeon until the otherwise Afrotropical species C. smaeleni Lestage (Baetidae) was recently discovered as introduced to Brazil [47].

Some families resemble one another very closely in different geographic regions, due to convergent evolution in different radiations of diversity. For example, the widespread family Leptophlebiidae contains species with forms of gills usually associated with other extant families [3,48].

\section{Roles in Ecosystem Services}

Ecosystem services are defined as the benefits that people obtain from ecosystems [49]. These services can be further categorized as either cultural, provisioning, regulating, or supporting services.

\subsection{Cultural Services}

Cultural services are non-material benefits and are typically difficult to define but include aesthetic, spiritual or religious values, inspirational and educational uses, and sense of place and cultural heritage [50].

The cultural significance of mayflies is important but easily overlooked, especially by Western cultures. Mayflies have been used to illustrate the fleeting and fragile nature of life in literature across cultures and throughout the ages. The earliest reference to mayflies in a written text can be found in the Epic of Gilgamesh, which dates from the 18th Century BC [51]. Mayflies and their short adult stage piqued the interest of early scientific writers such as Aristotle and Pliny the Elder. Chinese poets, such as Shi Su and An Liu, featured them in verse (see English translations included in [52]). Their importance in fly-fishing (see below) has led to their inclusion in a number of poems, including 'To an old friend' [53] which describes an angler and a trout waiting for the emergence of the first March brown mayfly of the year. Several music groups have had mayfly as part of their names.

The Tisza mayfly Palingenia longicauda (Olivier) (Palingeniidae) is celebrated in Hungary with an annual festival. In addition, a monument to the mayfly can be found at Szeged, and the Tiszavirág (i.e., blossom of the Tisza) bridge over the River Tisza at Szolnok is designed to resemble the mayfly in flight. Incidentally, the Tisza mayfly features in a Hungarian folk song as a symbol of a man's love [54]. One of us (LMJ) has visited the annual Bay-Rama Fishfly Festival held in June in New Baltimore, Michigan, United States of America (USA) (Figure 13); it is an event originally organized more in spite of the mass mayfly emergences of Ephemeridae from Lake St. Clair, rather than celebrating them. Another annual festival focused on mayflies occurs annually in Alagoas state, Brazil. These are a few examples that demonstrate the global cultural awareness of mayflies and the rites of intensification associated with them.

Mayflies are prominent features in some marketing campaigns. In England, for example, public houses are named after mayflies, and a number of real ales are named after mayflies. Major corporations have also employed mayflies as a marketing tool. Nike released a range of ultralight running shoes called 'Mayfly' in 2003, while Vodafone ran an award-winning $£ 100$ million marketing campaign in 2006 encouraging viewers to be like a mayfly and 'make the most of now'.

Mayflies have given their name to a number of vehicles. One of the first attempts at powered flight was made in 1908 in an aircraft called the Seddon Mayfly, and it was followed in 1910 by the Bland Mayfly, the first aircraft to be designed by a woman, Lillian Bland. Mayfly was used as the name for three British Royal Navy ships: a 1907 torpedo boat, an airship in 1911, and a Fly-class river gunboat in 1915.

The imitation of mayflies to catch fish dates back to the 1st century AD [55]. In 15th century Britain, patterns for artificial flies to mimic Rhithrogena germanica, Electrogena lateralis (Curtis) (Heptageniidae), 
and Heptagenia sulphurea were being published [56]. Fly-fishing is now a world-wide pastime enjoyed by millions of people. Various assessments have been made of the economic importance of fly-fishing. In the United Kingdom, for example, game fishing is worth $£ 498$ million to the economy annually $[57,58]$. In another example from the USA, some 25.4 million people are believed to participate in freshwater fishing, contributing US\$31.4 billion to the USA economy [59].

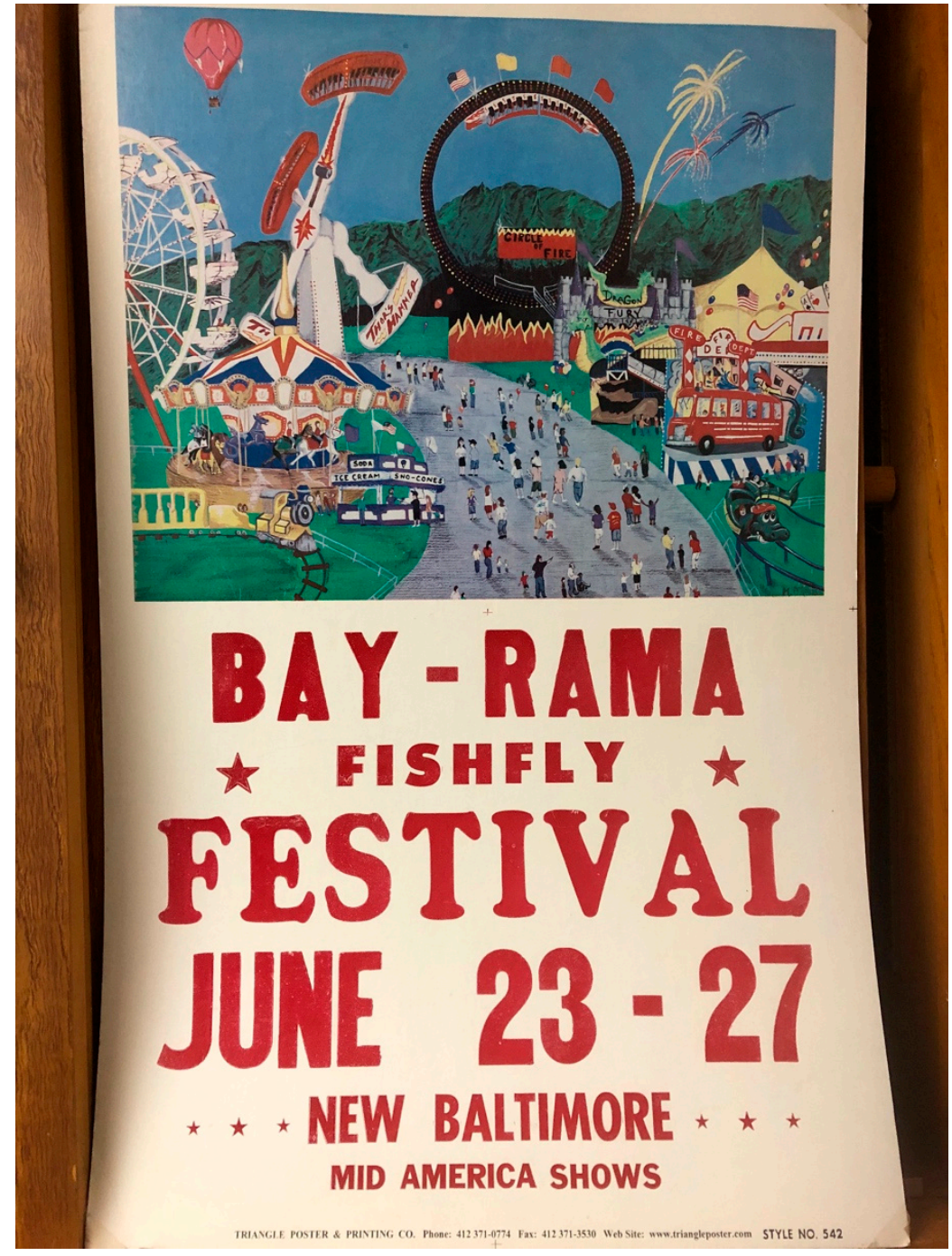

Figure 13. Advertising poster from "fishfly" festival in New Baltimore, Michigan, USA, ca. 2004. The annual celebration usually coincides with the mass emergence of Ephemeridae from Lake Saint Clair, which is located on the Michigan, USA and Ontario, Canada borderline.

\subsection{Provisioning Services}

Provisioning services describe material benefits obtained from ecosystems such as food for humans, safe freshwater, and genetic resources [50]. The following paragraphs describe the provisioning services in freshwater ecosystems provided by mayflies.

Despite their generally small size and delicate nature, mayflies are naturally high in protein, minerals, B vitamins, and essential amino acids, and low in fat [60] which makes them an important component of the human diet in some cultures. Human consumption of mayflies has been documented from 10 countries [61]. The mayflies of Lake Victoria are particularly important for local inhabitants. Swarms of Caenis kungu Eaton (Caenidae) and Povilla adusta are collected from along the shore-line, then either sun-dried and ground into flour, or made into a paste, and subsequently cakes and 
bread [60,62-64]. In a marketplace in a village on the East coast of Madagascar, one of us (MS) has seen baskets of Elassoneuria Eaton (Oligoneuriidae) larvae sold as "Mangoro River shrimps". Swarms of Plethogenesia Ulmer (Palingeniidae) are also collected in Papua New Guinea before being cooked and eaten [54]. In Indonesia, the Muyu people collect spent mayflies from the surface of rivers and creeks using mosquito nets. The catch is packed in wild banana leaves and roasted on embers or heated in a pan before being eaten [65]. Whilst adult mayflies are more commonly collected and eaten, 17th century Incas are reported to have eaten larvae of Euthyplocia Eaton (Euthyplociidae) either raw or by incorporating them into a spicy sauce [66]. The Nyishi and Galo tribes of India also used roasted or boiled larvae of the genus Ephemera Linnaeus (Ephemeridae) to treat stomach disturbances [67]. Alate stages and larvae of Teloganopsis jinghongensis ( $\mathrm{Xu}$, You \& Hsu) (Ephemerellidae) are eaten in China [68], having one of the highest protein contents by dry weight of any edible insect [69].

Mayflies are used for more than just food. Low molecular weight chitosan, which has antitumor activity [70], can be produced from their bodies. Living mayflies, such as the Triangle small minnow mayfly, Neocloeon triangulifer (McDunnough) (Baetidae), also have important uses. This species has become an important laboratory model organism, useful for advancing scientific endeavors and expanding human knowledge (e.g., see review in [71]).

\subsection{Regulatory Services}

Regulatory services are benefits obtained from processes such as the regulation of climate, water purification, and pollination [50]. Mayflies contribute, at least in small ways, to the regulatory services provided by ecosystems in that they process, break down and sometimes remove substances from water as larvae, as discussed elsewhere in this review. A number of mayfly genera, including some mentioned previously, filter fine particulate organic material from the water column as a source of food [72,73]. Mayflies remove substances from water when they emerge as subimagoes. Although many individuals return to the water and die, some are retained in terrestrial systems via predation or incidental death.

\subsection{Supporting Services}

Supporting services are necessary for the production of all other services and include nutrient cycling and primary production [50]. Mayflies provide many essential services that maintain and enhance ecosystem function. Burrowing species (e.g., Figure 8) such as Ephemera danica (Müller) (Ephemeridae), Hexagenia limbata (Serville) (Ephemeridae) (the Michigan Hex) or Campsurus violaceus Needham \& Murphy (Polymitarcyidae) contribute to both bioturbation and bioirrigation by reworking sediments in rivers and flushing water through their burrows (e.g., [74]). In one study [75], H. limbata was found to be responsible for up to $98 \%$ of the volume of sediment disturbed in Lake Saint Joseph, Canada. Another study [76] found that bioirrigation and bioturbation by Hexagenia spp. in Lake Erie resulted in soluble reactive phosphorus flux in the water column.

As just indicated, mayflies contribute in various ways to nutrient cycling (and spiraling) and energy flow. In a few special cases, mayflies also make a contribution to the decomposition of coarse woody debris and vegetation. Species from the genera Povilla Navás (Polymitarcyidae) and Asthenopus Eaton (Polymitarcyidae) burrow into submerged and rotten wood and living plants such as Typha Linnaeus (Poales: Typhaceae) and Eichornia Kunth (Commelinales: Pontederiaceae) [77,78], sometimes also causing damage to underwater structures and boats. Filter feeding by mayflies [72] has been assumed to contribute to water purification.

The abundance of mayflies makes them an important part of the diet of many species other than humans, as detailed above. As many as 224 species-including a range of other invertebrates (especially species of Arachnida and Odonata), birds, lizards and other reptiles, amphibians, bats and other mammals-feed upon mayflies [79-81]. Arguably the most important of these predator-prey relationships is the contribution of mayflies to the diet of fish. Many people around the world rely upon freshwater fish as a source of subsistence, not only as food, but also as a driver of the local economy [82]. 
The contribution of mayflies to the diet of freshwater fish varies considerably by species. While some fish species casually or incidentally feed on mayflies, other fish species rely almost exclusively on mayflies. In one example, $98 \%$ of the diet of the Oscar cichlid (Astronotus ocellatus (Agassiz) (Chordata: Actinopterygii: Cichliformes: Cichlidae)) is made up of mayflies [83].

In being an integral part of the diet of fish and other aquatic animals, mayflies serve as a link in the flow of energy between primary producers and secondary consumers. They may, for example, scrape and ingest periphyton from submerged surfaces and then be eaten by fish or other predators. Mayflies also may collect fine particulate organic matter (FPOM) and make energy and nutrients contained therein available to higher trophic levels in the aquatic community.

Mayflies not only move nutrients within aquatic ecosystems, but they also move nutrients between them. This may be important for maintaining a variety of aquatic communities, especially if various climate forecasts hold true. Some migrations of mayflies may prove to deliver food subsidies from productive but warming river mainstems to cool but food-limited tributaries, enhancing the resilience of cool-water predators in warming river networks. Ephemerella maculata Traver (Ephemerellidae), for example, has been shown to engage in such movements, and it was more important than terrestrial invertebrate subsidies to the early growth of a trout species [84].

Mayflies also play an important role in the cycling and transfer of nutrients and carbon between aquatic and terrestrial habitats. Although mayflies grow and develop in aquatic habitats, terrestrial detritus is the dominant nutrient source for at least the abdomen, head, and wings of the burrowing mayfly species, Ephemera danica [85]. The sediment, periphyton, and seston also play roles in the intertwined sources of nutrients for the species. Winged mayflies emerge from the water and enter the terrestrial realm, where they may be consumed by many riparian species such as birds, bats, spiders, and lizards (e.g., [79]). This represents, at least in part, their role in transferring matter from aquatic to terrestrial systems. In this role, however, it is important to consider that they also serve as a "biotransporter" of potentially problematic substances, such as waterborne contaminants, to terrestrial ecosystems [86]. Black bears (Ursus americanus) have been observed feeding on piles of dead mayflies in Canada [87], but more study is needed on this and whether they play any significant role in transferring contaminants directly to large mammals.

Mayfly larvae also serve as habitat for other organisms. Mayfly species are known to host commensal bryozoans [88], protozoans [89,90], and chironomid midges [90-94]. They are also hosts to various fungi [95,96], nematodes [97-104], and trematodes [99,105].

Together with other macroinvertebrates, aquatic insects-especially mayflies-have become an important tool for monitoring the quality of freshwaters (e.g., see [106-108]) and their associated terrestrial riparian habitats, due to the essential roles these arthropods play in aquatic ecosystems, their sensitivity to change, and our increasing abilities to collect and identify them. Mayflies, at the order and various subordinate taxonomic levels, have become well-known for their use in these efforts (e.g., [109-112]), which are applied to the protection of both biodiversity and human water supplies throughout the world (e.g., [113-122]).

Mayflies fulfil the criteria for good indicators because they are: (i) abundant and sufficiently diverse in their habits and habitats, (ii) sensitive and predictable in their response to changes in environmental conditions, (iii) relatively easily sampled and identifiable to meaningful taxonomic resolutions, and (iv) bioaccumulate chemicals such that the pathways of toxins in the environment can be traced $[123,124]$. As biological indicators, their response to changing conditions is integrated over time and space, potentially lowering sampling effort and cost compared to the high intensity of sampling often required when relying on chemical variables to detect certain impacts [125]. An additional benefit, particularly in economically disadvantaged areas, is the lack of specialized equipment and supplies needed for collecting mayfly data, in contrast to chemical data [126].

As mentioned previously, mayflies are identified relatively easily to the order level. With minimal education, mayflies can be further identified to the family level, even in the field after being collected with simple nets or seines. A South African tool called "miniSASS" (www.minisass.org) is now 
implemented in some places on relatively remote Indian Ocean islands and allows a rapid measure of general river health and water quality by children or adults. In the UK, the Riverfly Partnership has developed a simple monitoring method, targeted at anglers and other river users, which is now being used by over 3000 volunteers to monitor around 800 sites [127]. As such, species of Ephemeroptera are arguably among the most useful bioindicators and provide a scoring index that is easy to use [128].

Mayfly community composition changes in response to alterations of a variety of environmental variables [129]. Their broad ranges of functional traits and differential tolerances to anthropogenic factors have been noted widely and are either used, or have the potential for use, in the development of biotic indices to monitor agricultural practices [130], organic pollution [108,131-133], eutrophication [134,135], flow quantity [136], acidification [137], mine drainage [138], drought [139], sediment and silt loading [129,140], pesticide pollution [141], physical habitat alteration [142], invasive species [120], blooms of cyanobacteria [143] and climate-change vulnerability, particularly in long-lived species, and those living at higher altitudes and other areas where periods of drought may increase [144-146]. Mayflies also respond to changes in temperature [147-154]. As 'biosentinels', aquatic insects have been used to monitor levels of a variety of heavy metals [155], methylmercury [156], mercury [157,158], selenite [159], and uranium [160] in freshwater ecosystems. In particular, larvae are sensitive to low levels of nitrates in the water [161-163] and also to changes in phosphorus [134]. In one example [164], phosphorus enrichment actually increased mayfly growth rates. Further work is required to determine whether the species' sensitivities are due to the increased growth of bacteria on their bodies under these conditions [165] or to increased cyanobacterial populations, perhaps moreso than to the nutrients themselves. Regarding changes in $\mathrm{pH}$, it has been found that differential sensitivities exist at the species level [166]. Acidification, in particular, may play a role in community structure [167].

\section{Challenges to Mayfly Services}

The continued provisioning of ecosystem services by mayflies is reliant on healthy populations of the species that deliver them. Global freshwater biodiversity is reported to have declined by $83 \%$ since 1970, with greatest losses in the Neotropics, Indo-Pacific, and Afrotropics [168]. Whilst this analysis did not include invertebrates, we see no reasons to suggest that similar declines have not occurred. Another study reported that general flying insect biomass has decreased by 76\% or more in some areas [169]. Aquatic insect species, in particular, likely are experiencing similar declines. A survey of trout anglers in southern England reported a perceived $66 \%$ reduction in the number of freshwater insects emerging from chalk streams since the 1970s [170], and in a recent assessment of red lists based on the IUCN assessment criteria [171] from around the world, 15\% of dragonflies and damselflies (Odonata) were found to be at threat of extinction [172]. Sound evaluations of the conservation status of mayfly species are generally lacking globally. A few areas, however, have conducted such evaluation. In Switzerland, for example, a recent red list evaluated $43 \%$ of Ephemeroptera as at least endangered [173], whereas in France, this proportion is $22 \%$ [174]. Differing criteria used for evaluation make direct comparisons between studies difficult, and methods should be evaluated carefully. Some apparently threatened species are found in habitats that are difficult to study, as is the case for South Carolina, USA [175], leading to the possibility that some species simply are under-represented in stream samples. Clearly, more work is needed towards assessing the conservation status of mayfly species worldwide, but the percentage of imperiled mayfly species may be very near to the percentage of threatened odonates mentioned above (15\%). Besides the loss of species diversity, concern also should be directed towards decreases in genetic diversity, which may lead to populations that are less able to adapt to changing conditions and more prone to effects of genetic drift.

The following pressures should be managed to help conserve mayfly populations and by extension, the ecosystem services they provide. 


\subsection{Pollution}

Pollution can affect not just the presence and abundance of specific insect taxa but also their ability to perform ecosystem services through altering their physical status [176] at levels ranging from the individual to the cellular. Fine sediments cause river impairment with consequences for freshwater insect abundance [177,178], functional traits [179], biomass [180], and species richness [181]. Even in cases where pollutants may not affect mayflies directly, individuals that have accumulated pollutants in their bodies may play a role in problems associated with others parts of ecosystems. For example, as part of their role in cycling matter between aquatic and terrestrial habitats, mayflies accumulate heavy metals from the water and sediment and transfer them elsewhere [182]. Heavy metals sometimes are lost during metamorphosis, however. It also is worthwhile to note that differences in tissue concentrations may exist between males and females [183]; such differences should be explored, along with any ramifications associated with differential dispersal of males and females.

Despite the introduction of legislation such as the Water Framework Directive in Europe and the Clean Water Act (CWA) in the USA, pollution continues to impact water quality in rivers around the world. Almost half of the sites monitored across Europe continue to suffer from chronic chemical pollution leading to long-term negative impacts on freshwater organisms [184]. One in ten sites suffered acute pollution with potentially lethal impacts for freshwater organisms. Sources of pollution included domestic and industrial sewage effluents and run-off from agriculture and urban areas, with pesticides posing the most acute risk to freshwater ecosystems. The impact of neonicotinoid pesticides is particularly worrying (e.g., $[185,186])$.

Diversity and overall abundance of freshwater invertebrates were significantly reduced in water chronically polluted with the pesticide imidacloprid [187]. Mayflies, caddisflies, and true-flies are particularly sensitive to these pesticides; even at low concentrations, there is a considerable risk of widespread impact on freshwater invertebrate populations [188]. In laboratory tests, half of mayflies and caddisflies died when exposed to concentrations in the range $0.1-0.3 \mu \mathrm{g} / \mathrm{L}$; at just $0.03 \mu \mathrm{g} / \mathrm{L} 10 \%$ of mayflies died. Sub-lethal effects on invertebrates have also been detected, including changes in feeding rates, mobility, predation rates, reduced growth, and reduced emergence at levels between 0.3 and $1.5 \mu \mathrm{g} / \mathrm{L}$ [189]. Monitoring of watercourses in the UK has shown surprisingly high concentrations of imidacloprid in urban catchments, and it is suggested that domestic pet flea (Siphonaptera) treatments may be the mostly likely source [190].

A recently published study of waters in Australia [191] showed the prevalence and diversity of pharmaceuticals present in the stream and riparian food webs, especially among aquatic insects and spiders. More work is needed to study the movement of these compounds through connections of aquatic and terrestrial food webs; mayflies no doubt play a role here, linking pieces of the landscape mosaic. Beyond pharmaceutical pollution, general organic pollution may have complex effects; for example, further research is required to evaluate the importance of reduced zinc bioavailability associated with increased organic matter and water hardness to the species-poor communities in organic-contaminated rivers [192].

\subsection{Invasive Alien Species}

Invasive Alien Species (IAS) are an increasing threat throughout the World. In Europe, many of these non-native species originate from the Ponto-Caspian region, with over a hundred species known to have spread from this area to date [193]. The introduction of these non-native species to new ecosystems ultimately leads to a reduction in species richness and abundance, with mayflies, caddisflies, freshwater shrimps and other crustaceans particularly vulnerable. A list of 100 of the World's worst invasive species features 9 freshwater invertebrates, including the Chinese mitten crab (Eriocheir sinensis H. Milne-Edwards (Decapoda: Varunidae)), the Fish-hook water flea (Cercopagis pengoi (Ostroumov) (Cladocera: Cercopagididae)) and Golden apple snail (Pomacaea canaliculata (Lamarck) (Gastropoda: Ampullariidae)) [194]. In Europe, crayfish species pose a particular threat, especially Signal crayfish (Pacifastacus leniusculus (Dana) (Decapoda: Astacidae)) and Red swamp crayfish (Procambarus clarkii 
(Girard) (Decapoda: Cambaridae)). The annual cost incurred due to damage caused by and/or the control of these species has been estimated at $€ 454$ million [195]. In the UK, a list of 56 invasive alien invertebrate species features 24 freshwater species [196], whereas, at the scale of Europe, more than 750 alien freshwater species have been recorded [197].

\subsection{Habitat Loss and Degradation}

Freshwater habitats are the most extensively and rapidly altered ecosystems on the planet, and they demonstrate broad response to these modifications, including changes to physical structure, chemistry, biotic characteristics and ecosystem processes [198].

Continued investment in hydro-power electricity generation is predicted to result in a $21 \%$ decrease in the number of remaining free-flowing rivers around the world. The majority of these developments are focused on the Amazon in South America, the Ganges in India, and the Yangtze in China [199]. Once impoundments are established, dam failures pose risks not only for humans downstream but also for aquatic life, including mayflies, both up- and downstream. This has been indicated for a recently discovered mayfly species, Tricorythodes tragoedia Souto, Angeli \& Salles [200]. River drainage and flood-protection schemes involving the alteration of watercourses also cause changes to habitat conditions.

Dams and diversions may lead to changed conditions both up- and downstream, resulting in a changed habitat that may no longer support populations once prevalent [201]. Fragmented and isolated populations may be more prone to the effects of extreme genetic drift or extirpation when subjected to sporadic droughts and scouring from floods, which is especially problematic for species that inhabit marginal, shallow, and erosional zones of streams.

Development of urban areas and transportation infrastructure also impacts freshwater invertebrates in many ways. Perhaps seldom considered, the steady increase in the intensity and distribution of lights next to rivers may have a negative impact on populations. The adults of many species are attracted to light and bankside lights may lure them away from their natural waterside habitat (e.g., [202]). Similarly, asphalt roads can act as an ecological trap for mayflies, which are attracted to the horizontally polarized light reflected from their surfaces [203]. Solar panels are known to cause the same phenomenon [204], and the proliferation of this renewable energy source in recent years is a cause for concern, from the perspective of Ephemeroptera conservation. Fortunately, relatively simple mitigation measures can reduce the attractiveness of these panels [205].

A further impact of development is the placing of bridges over watercourses [206]. Upon approaching a bridge, up to $86 \%$ of Long-tailed mayflies (Palingenia longicauda) turn back rather than cross the bridge to continue upstream [207]. This is particularly problematic as it disrupts the compensatory upstream mating flight of the mayfly, thus restricting its range in the river. Further studies should explore the behaviors of other species with respect to bridges. Also, involving roadways in part, salinization of freshwaters is being seen as an emerging threat [208]. Baseline toxicity studies on pollution with fracking wastewater on three mayfly species in the Delaware river basin found chronic lethal effects after exposure over 20-30 days with a concentration of $0.5 \%$ produced water. In addition, non-lethal effects, including reduced reproductive rate and smaller adult size, were observed [209].

Degradation and loss of terrestrial habitat also impact mayfly communities. In addition to declines in water purification and flood mitigation, terrestrial degradation and loss via water erosion impact mayfly larvae. As silt and sediment loads increase in water bodies, larval populations of taxa intolerant to these loads (perhaps the majority of taxa) are challenged, but a few others, such as Caenis and some Eurylophella Tiensuu (Ephemerellidae) (genera with operculate gills) and many burrowers (which prefer soft substrate) benefit, either due to competitive release or more abundant potential habitat.

\subsection{Climate Change}

Climate change is widely recognized as being one of the major long-term threats to biodiversity [210]. Most recent predictions are that the average global temperature will continue to rise as a result of climate 
change, and this will inevitably have an impact on invertebrate populations. Indeed, with the majority of mayfly species having relatively short life cycles and good powers of mobility, they are likely to be one of the first groups to show the impact of a changing climate [211,212]. Cold-loving species may retreat northwards and uphill, while warm-loving species may increase their range [210]. However, many tropical and equatorial species evolved within narrow thermal regimes and already are living near their thermal maxima; even slight changes may outpace their ability to move or otherwise adapt [210]. An analysis of European Trichoptera species traits found that the biggest potential impact from climate change was likely in Southern Europe with up to 30\% of the fauna in the Iberic-Macaronesian region being potentially endangered by climate change [213]. In the UK one study [214] found that a $3{ }^{\circ} \mathrm{C}$ rise in temperature could result in a $10-43 \%$ reduction in macroinvertebrate abundance in upland circumneutral streams and lead to the local extinction of at least the Gold-ringed dragonfly (Cordulegaster boltonii (Donovan) (Odonata: Cordulegastridae)), a caddisfly species (Rhyacophila munda R. McLachlan (Trichoptera: Rhyacophilidae)), and Pea mussels (species of Pisidium Pfeiffer (Bivalvia: Sphaeriida: Sphaeriidae)). The Upland summer mayfly (Ameletus inopinatus Eaton (Ameletidae), also known as the Holarctic comb minnow mayfly) - a predominately montane mayfly species restricted to coldwater streams-is now absent at many of its historical sites at lower altitudes, and some evidence suggests that it is being pushed further and further upstream as water temperatures rise [215]. European research using climate change models has shown that the geographical range of this species is likely to contract with remaining populations predicted to be restricted to the Alps, Scandinavia and parts of the Scottish Highlands such as the Cairngorms by 2080 [216]. In contrast, another study [217] found that numbers of emergent Ephemeroptera were unaffected by brownification and warming, under experimental conditions in a large-scale outdoor pond facility; this may suggest some differences between potential responses of lentic and lotic mayfly species assemblages that warrant further investigation.

It is unclear how an expanded season of meltwater will affect mayfly communities in streams fed in this way. More meltwater may lead to overall cooler conditions for these streams, rather than warmer conditions, for at least some of the year, and it may possibly lead also to periods of less thermal fluctuation than normal. All of these changes may pose challenges to the phenologies of species that have evolved in these streams, especially timing aspects related to egg diapause; alternatively, it might lead to range expansions or increases in population sizes.

\section{Conclusions}

Despite being a relatively small order of insects, mayflies deliver a wide variety of direct and indirect ecosystem services. They are excellent indicators of the condition of their habitats, in addition to delivering services such as providing food for humans and other animals, reworking sediments, decomposing wood and other vegetation, and purifying water through filter feeding. Future study of their feeding behaviors and general habits may reveal further ecosystems services provided by mayflies.

However, the continued provision of these services may be jeopardized by anthropogenic impacts such as pollution, invasive alien species, habitat loss and degradation, and climate change. Further efforts to assess the conservation status of mayfly species worldwide are required, and where appropriate, action should be taken to ensure that species are resilient to these impacts.

Concerted and coordinated actions worldwide to minimize, manage, and mitigate these impacts are necessary so that future generations may continue to benefit from the services provided by Ephemeroptera.

Author Contributions: Conceptualization, L.M.J.; investigation, L.M.J., C.R.M., M.S.; writing—original draft preparation, L.M.J., C.R.M., M.S.; writing—review and editing, L.M.J., C.R.M., M.S.; visualization, M.S.

Acknowledgments: John Morse and Peter Adler (Clemson University) solicited and encouraged this article. Some images were provided by Frederico Salles (Universidade Federal de Viçosa) and Laurent Vuataz (Museum of Zoology, Lausanne). A thorough peer-review by five anonymous colleagues contributed to improvements of this work. Rongrong Leng served as editor. 
Conflicts of Interest: The authors declare no conflict of interest.

\section{References}

1. Herd, A. The History of Fly Fishing; Medlar Press: Ellesmere, UK, 2011; p. 440.

2. Dethier, V.G. To Know a Fly; Holden-Day: San Francisco, CA, USA, 1962.

3. Edmunds, G.F.; Jensen, S.L.; Berner, L. The Mayflies of North and Central America; University of Minnesota Press: Minneapolis, MN, USA, 1976; p. 330.

4. Corkum, L.D. Spatial-temporal patterns of recolonizinig adult mayflies in Lake Erie after a major disturbance. J. Gt. Lakes Res. 2010, 36, 338-344. [CrossRef]

5. Reynolds, D.R.; Riley, J.R. Radar observations of concentrations of insects above a river in Mali, West Africa. Ecol. Entomol. 1979, 4, 161-174. [CrossRef]

6. McCafferty, W.P. Aquatic Entomology-The Fishermen's and Ecologists' Illustrated Guide to Insects and Their Relatives; Science Books International: Boston, MA, USA, 1981; p. 448.

7. Knopp, M.; Cormier, R. Mayflies: An Angler's Study of Trout Water Ephemeroptera; Greycliff Publishing Company: Helena, MT, USA, 1997; p. 366.

8. Beattie, A.; Ehrlich, P.R. Wild Solutions: How Biodiversity Is Money in the Bank; Yale University Press: New Haven, CT, USA, 2001; p. 239.

9. Edmunds, G.F.; McCafferty, W.P. The mayfly subimago. Annu. Rev. Entomol. 1988, 33, 509-529. [CrossRef]

10. Peters, W.L.; Peters, J.G. Adult life and emergence of Dolania americana in northwestern Florida (Ephemeroptera: Behningiidae). Internationale Revue der Gesamten Hydrobiologie und Hydrographie 1977, 62, 409-438. [CrossRef]

11. Gillies, M.T. The adult stages of Prosopistoma Latreille (Ephemeroptera) with descriptions of two new species from Africa. Trans. R. Entomol. Soc. Lond. 1954, 105, 355-372. [CrossRef]

12. Lafon, J. Note sur Prosopistoma foliaceum Fourc. (Ephéméroptère). Bulletin de la Société Zoologique de France 1952, 77, 425-436.

13. Kluge, N.J. The Phylogenetic System of Ephemeroptera; Kluwer Academic Publishers: Dordrecht, The Netherlands, 2004; p. 442.

14. Fremling, C.R. Environmental synchronization of mass Hexagenia bilineata (Ephemeroptera) emergences from the Mississipi River. Verhandlungen der Internationale Verein für Limnologie 1973, 18, 1521-1526.

15. Edmunds, G.F. Exuviation of subimaginal Ephemeroptera in flight. Entomol. News 1956, 67, 91-93.

16. Funk, D.H.; Sweeney, B.W.; Jackson, J.K. Why stream mayflies can reproduce without males but remain bisexual: A case of lost genetic variation. J. N. Am. Benthol. Soc. 2010, 29, 1258-1266. [CrossRef]

17. Edmunds, G.F. Ovoviviparous mayflies of the genus Callibaetis. Entomol. News 1945, 56, 169-171.

18. Degrange, C. L'ovolarviparité de Cloeon dipertum (L.) (Ephemereptera, Baetidae). Bulletin de la Société Zoologique de France 1959, 64, 94-100.

19. Cianciara, S. Life cycles of Cloeon dipterum (L.) in natural environment. Polskie Archiwum Hydrobiologii 1979, 26, 501-513.

20. Sweeney, B.W.; Vannote, R.L. Variation and the distribution of hemimetabolous aquatic insects: Two thermal equilibrium hypotheses. Science 1978, 200, 444-446. [CrossRef] [PubMed]

21. Berner, L. The occurence of mayfly nymphs in Brackish water. Ecology 1954, 35, 98. [CrossRef]

22. Chadwick, M.A.; Hunter, H.; Feminella, J.W.; Henry, R.P. Salt and water balance in Hexagenia limbata (Ephemeroptera: Ephemeridae) when exposed to brackish water. Fla. Entomol. 2002, 85, 650-651. [CrossRef]

23. Austin, D.A.; Baker, J.H. Fate of bacteria ingested by larvae of the freshwater mayfly, Ephemera danica. Microb. Ecol. 1988, 15, 323-332. [CrossRef] [PubMed]

24. Hynes, H.B.N. The Ecology of Running Waters; University of Toronto Press: Toronto, ON, Canada, $1970 ;$ p. 555.

25. Zahradkova, S.; Soldan, T.; Bojkova, J.; Helesic, J.; Janovska, H.; Sroka, P. Distribution and biology of mayflies (Ephemeroptera) of the Czech Republic: Present status and perspectives. Aquat. Insects 2009, 31, 629-652. [CrossRef]

26. Soluk, D.A.; Craig, D.A. Vortex feeding from pits in the sand: A unique method of suspension feeding used by a stream invertebrate. Limnol. Oceanogr. 1988, 33, 638-645. [CrossRef] 
27. Cavaletto, J.F.; Nalepa, T.F.; Fanslow, D.L.; Schloesser, D.W. Temporal variation of energy reserves in mayfly nymphs (Hexagenia spp.) from Lake St Clair and western Lake Erie. Freshw. Biol. 2003, 48, 1726-1738. [CrossRef]

28. Petr, T. Macroinvertebrates of flooded trees in the man-made Volta lake (Ghana) with special reference to the burrowing mayfly Povilla adusta Navas. Hydrobiologia 1970, 36, 373-398. [CrossRef]

29. Gattolliat, J.-L.; Sartori, M. Predaceous Baetidae in Madagascar: An uncommon and unsuspected high diversity. In Trends in Research in Ephemeroptera and Plecoptera; Dominguez, E., Ed.; Kluwer Academic/Plenum Publishers: New York, NY, USA, 2001; pp. 321-330.

30. Waltz, R.D.; Burian, S.K. Chapter 11: Ephemeroptera. In An introduction to the Aquatic Insects of North America; Merritt, R.W., Cummins, K.W., Berg, M.B., Eds.; Kendall/Hunt: Dubuque, IA, USA, 2008; pp. 181-236.

31. Gillies, M.T.; Elouard, J.-M. The mayfly-mussel association, a new example from the River Niger Basin. In Mayflies and Stoneflies: Life Story and Biology; Campbell, I.C., Ed.; Kluwer Academic Publishers: Dordrecht, The Netherlands, 1990; Volume 44, pp. 289-298.

32. Kukalova-Peck, J. Ephemeroid wing venation based upon new gigantic Carboniferous mayflies and basic morphology, phylogeny, and metamorphosis of pterygote insects (Insecta, Ephemerida). Can. J. Zool. 1985, 63, 933-955. [CrossRef]

33. Cai, Y.Y.; Gao, Y.J.; Zhang, L.P.; Yu, D.N.; Storey, K.B.; Zhang, J.Y. The mitochondrial genome of Caenis sp (Ephemeroptera: Caenidae) and the phylogeny of Ephemeroptera in Pterygota. Mitochondrial DNA Part B-Resour. 2018, 3, 577-579. [CrossRef]

34. Simon, S.; Blanke, A.; Meusemann, K. Reanalyzing the Palaeoptera problem-The origin of insect flight remains obscure. Arthropod Struct. Dev. 2018, 47, 328-338. [CrossRef] [PubMed]

35. Thomas, J.A.; Trueman, J.W.H.; Rambaut, A.; Welch, J.J. Relaxed Phylogenetics and the Palaeoptera Problem: Resolving Deep Ancestral Splits in the Insect Phylogeny. Syst. Biol. 2013, 62, 285-297. [CrossRef] [PubMed]

36. Ogden, T.H.; Gattolliat, J.L.; Sartori, M.; Staniczek, A.H.; Soldán, T.; Whiting, M.F. Towards a new paradigm in mayfly phylogeny (Ephemeroptera): Combined analysis of morphological and molecular data. Syst. Entomol. 2009, 34, 616-634. [CrossRef]

37. Barber-James, H.M. Freshwater invertebrate fauna of the Tristan da Cunha islands (South Atlantic Ocean), with new records for Inaccessible and Nightingale Islands. Trans. R. Soc. S. Afr. 2007, 62, 24-36. [CrossRef]

38. Clark, R.; Cooper, E.A.; MacFadyen, A.; Shipp, T.; Simpson, M.N.; Wilson, P. The Cumbria and Lancashire Falklands Expedition 1989. Falkl. Islands J. 1990, 5, 5-15.

39. Bauernfeind, E.; Soldán, T. The Mayflies of Europe; Apollo Books: Ollerup, Denmark, 2012; p. 781.

40. Böcher, J.; Kristensen, N.P. Ephemeroptera. In The Greeland Entomofauna; an Identification Manual of Insects, Spiders and Their Allies; Böcher, J., Kristensen, N.P., Pape, T., Vilhelmsen, L., Eds.; Brill: Leiden, The Netherlands, 2015; pp. 83-84.

41. Rutschmann, S.; Detering, H.; Simon, S.; Funk, D.H.; Gattolliat, J.-L.; Hughes, S.J.; Raposeiro, P.M.; DeSalle, R.; Sartori, M.; Monaghan, M.T. Colonization and diversification of aquatic insects on three Macaronesian archipelagos using 59 nuclear loci derived from a draft genome. Mol. Phylogenet. Evol. 2017, 107, 27-38. [CrossRef]

42. Rutschmann, S.; Gattolliat, J.L.; Hughes, S.J.; Baez, M.; Sartori, M.; Monaghan, M.T. Evolution and island endemism of morphologically cryptic Baetis and Cloeon species (Ephemeroptera, Baetidae) on the Canary Islands and Madeira. Freshw. Biol. 2014, 59, 2516-2527. [CrossRef]

43. Hofmann, C.; Sartori, M.; Thomas, A.G.B. Les Ephéméroptères (Ephemeroptera) de la Guadeloupe (petites Antilles françaises). Mémoires de la Société Vaudoise des Sciences Naturelles 1999, 20, 1-96.

44. McCafferty, W.P. Ephemeroptera and the great American interchange. J. N. Am. Benthol. Soc. 1998, 17, 1-20. [CrossRef]

45. Sartori, M.; Brittain, J.E. Order Ephemeroptera. In Ecology and General Biology, Vol I: Thorp and Covich's Freshwater Invertebrates, 4th ed.; Thorp, J.H., Rogers, D.C., Eds.; Academic Press: New York, NY, USA, 2015; pp. 873-891. [CrossRef]

46. Kluge, N.J. Contribution to the knowledge of Choroterpes (Ephemeroptera: Leptophlebiidae). Russ. Entomol. J. 2012, 21, 273-306. [CrossRef]

47. Salles, F.F.; Gattolliat, J.-L.; Angeli, K.B.; De-Souza, M.R.; Goncalves, I.C.; Nessimian, J.L.; Sartori, M. Discovery of an alien species of mayfly in South America (Ephemeroptera). Zookeys 2014, 1-16. [CrossRef] [PubMed] 
48. Peters, W.L.; Peters, J.G.; Edmunds, G.F. The Leptophlebiidae of New Caledonia (Ephemeroptera). Part I. Introduction and systematics. Cahiers de l'ORSTOM Série Hydrobiologie 1978, 12, 97-117.

49. Millenium Ecosystem Assessment. Ecosystems and Human Well-Being: Synthesis; World Resources Institute: Washington, DC, USA, 2005.

50. Millenium Ecosystem Assessment. Ecosystems and Human Well-Being: A Framework for Assessment; World Resources Institute: Washington, DC, USA, 2003.

51. Soldán, T. Mayflies (Ephemeroptera): One of the earliest insect groups known to man. In Ephemeroptera $\mathcal{E}$ Plecoptera Biology-Ecology-Systematics; Landolt, P., Sartori, M., Eds.; Mauron+Tinguely \& Lachat SA: Fribourg, Switzerland, 1997; pp. 511-513.

52. Zhou, C.F.; Su, C.R.; Gui, H. Outline of Chinese Mayflies; Science Press: Beijing, China, 2015. (In Chinese)

53. Chalmers, P.R. Green Days and Blue Days; Maunsel and Company Ltd.: Dublin, Ireland, 1912.

54. Szent-Ivany, J.J.H.; Ujhary, E.I.V. Ephemeroptera in the regimen of some New Guinea people and in Hungarian folksongs. Eatonia 1973, 17, 1-6.

55. Radcliffe, W. Fishing from the Earliest Times; John Murray: London, UK, 1921.

56. Berners, J. A Treatyse of Fysshynge Wyth an Angle (in The Boke of St Albans); W. Satchell and Son: London, UK, 1496.

57. Mawle, G.W.; Peirson, G. Economic Evaluation of Inland Fisheries; Environment Agency: Bristol, UK, 2009.

58. Radford, A.; Riddington, G.; Anderson, J. The Economic Impact of Game and Coarse Fishing in Scotland; Report Prepared for Scottish Executive Environment and Rural Affairs Department: Edinburgh, Scotland, 2004.

59. Prather, C.M.; Pelini, S.L.; Laws, A.; Rivest, E.; Woltz, M.; Bloch, C.P.; Del Toro, I.; Ho, C.K.; Kominoski, J.; ScottNewbold, T.A.; et al. Invertebrates, ecosystem services and climate change. Biol. Rev. 2013, 88, 327-348. [CrossRef] [PubMed]

60. Bergeron, D.; Bushway, R.J.; Roberts, F.L.; Kornfield, I.; Okedi, J. The nutrient composition of an insect flour sample from Lake Victoria, Uganda. J. Food Compos. Anal. 1988, 1, 371-377. [CrossRef]

61. Macadam, C.R.; Stockan, J.A. The diversity of aquatic insects used as human food. J. Insects Food Feed 2017, 3, 203-209. [CrossRef]

62. Fladung, E.B. Insects as Food; Maryland Academy Sciences Bulletin: Baltimore, MD, USA, 1924; pp. 5-8.

63. Mathooko, J.M. Mayfly diversity in East Africa. Afr. J. Ecol. 1998, 36, 368-370. [CrossRef]

64. Van Huis, A. Edible insects contributing to food security. Agric. Food Secur. 2015, 4, 20. [CrossRef]

65. Ramandey, E.; van Mastrigt, H. Edible insects in Papua, Indonesia: From delicious snack to basic need. In Forest Insects as Food: Humans Bite Back, Proceedings of the Workshop on Asia-Pacific Resources and Their Potential for Development, Chiang Mai, Thailand, 19-21 February 2008; Durst, P.B., Johnson, D.V., Leslie, R.N., Shono, K., Eds.; FAO: Rome, Italy, 2010; pp. 105-114.

66. Gillies, M.T. Mayflies as food: A confused story from South America. Mayfly Newsl. 1996, 6, 1.

67. Chakravorty, J.; Gosh, S.; Meyer-Rochow, V.B. Comparative Survey of Entomophagy and Entomotherapeutic Practices in Six Tribes of Eastern Arunachal Pradesh (India). J. Ethnobiol. Ethnomed. 2013, 9, 50. [CrossRef] [PubMed]

68. Chen, X.-M.; Feng, Y. The Edible Insects of China; Science and Technology Publishing House: Beijing, China, 1999.

69. Chen, X.-M.; Feng, Y.; Chen, Z. Common edible insects and their utilization in China. Entomol. Res. 2009, 39, 299-303. [CrossRef]

70. Tan, G.; Kaya, M.; Tevlek, A.; Sargin, I.; Baran, T. Antitumor activity of chitosan from mayfly with comparison to commercially available low, medium and high molecular weight chitosans. In Vitro Cell. Dev. Biol.-Anim. 2018, 54, 366-374. [CrossRef] [PubMed]

71. Chou, H.; Pathmasiri, W.; Deese-Spruill, J.; Sumner, S.; Buchwalter, D.B. Metabolomics reveal physiological changes in mayfly larvae (Neocloeon triangulifer) at ecological upper thermal limits. J. Insect Physiol. 2017, 101, 107-112. [CrossRef]

72. Wallace, J.B.; Merritt, R.W. Filter-feeding ecology of aquatic insects. Annu. Rev. Entomol. 1980, 25, 103-132. [CrossRef]

73. Wallace, J.B.; O'Hop, J. Fine particle suspension-feeding capabilities of Isonychia spp. (Ephemeroptera: Siphlonuridae). Ann. Entomol. Soc. Am. 1979, 72, 353-357. [CrossRef] 
74. Clemente, J.; Kroger, A.; Goyenola, G.; Teixera-de-Mello, F.; Maroni, S.; Fosalba, C.; Iglesias, C.; Matteo, N. Campsurus violaceus (Ephemeroptera, Polymitarcyidae) in a subtropical reservoir: Control factors and relationship with the macroinvertebrate community. Pan-Am. J. Aquat. Sci. 2018, 13, 241-253.

75. Charbonneau, P.; Hare, L. Burrowing behavior and biogenic structures of mud-dwelling insects. J. N. Am. Benthol. Soc. 1998, 17, 239-249. [CrossRef]

76. Chaffin, J.D.; Kane, D.D. Burrowing mayfly (Ephemeroptera: Ephemeridae: Hexagenia spp.) bioturbation and bioirrigation: A source of internal phosphorus loading in Lake Erie. J. Gt. Lakes Res. 2010, 36, 57-63. [CrossRef]

77. Berner, L. The status of Asthenopus curtus (Hagen) (Ephemeroptera: Polymitarcyidae). Acta Amazonica 1978, 8, 103-105. [CrossRef]

78. Satter, W. Über die Lebensweise, insbesondere das Bauverhalten, neotropischer Eintagsfliegen-Larven (Ephemeroptera, Polymitarcyidae). Beiträge zur Neotropischen Fauna 1967, 5, 89-110. [CrossRef]

79. Baxter, C.V.; Fausch, K.D.; Saunders, W.C. Tangled webs: Reciprocal flows of invertebrate prey link streams and riparian zones. Freshw. Biol. 2005, 50, 201-220. [CrossRef]

80. Grant, P.M. Mayflies as food. In Trends in Research in Ephemeroptera and Plecoptera; Dominguez, E., Ed.; Kluwer Academic/Plenum Publishers: New York, NY, USA, 2001; pp. 107-124.

81. Macadam, C.R.; Stockan, J.A. More than just fish food: Ecosystem services provided by freshwater insects. Ecol. Entomol. 2015, 40, 113-123. [CrossRef]

82. Sangpradub, N.; Sonmark, R.; Hanjavanit, C. Food of Anematichthys repasson and Ompok bimaculatus from Kaeng Lawa, Thailand. AACLBioflux 2014, 7, 419-429.

83. Godhino dos Reis, L.R.; de Alcantara Santos, A.C. Dieta de duas especies de peixes da familia Cichlidae (Astronotus ocellatus e Cichla pinima) introduzidos no rio Paraguacu, Bahia. Biotemas 2014, 27, 83-91.

84. Uno, H.; Power, M.E. Mainstem-tributary linkages by mayfly migration help sustain salmonids in a warming river network. Ecol. Lett. 2015, 18, 1012-1020. [CrossRef] [PubMed]

85. Yohannes, E.; Rothhaupt, K.-O. Dietary nutrient allocation to somatic tissue synthesis in emerging subimago freshwater mayfly Ephemera danica. BMC Ecol. 2018, 18, 57. [CrossRef] [PubMed]

86. Walters, D.M.; Fritz, K.M.; Otter, R.R. The dark side of subsidies: Adult stream insects export organic contaminants to riparian predators. Ecol. Appl. 2008, 18, 1835-1841. [CrossRef]

87. Seton, E.T. Life History of Northern Animals; Charles Scribner's and Sons: New York, NY, USA, 1909 ; p. 698.

88. Ogbogu, S.S. A phoretic association between a bryozoan and an insect in a Nigerian lake. J. Trop. Ecol. 1993, 9, 125-126. [CrossRef]

89. Abrahao, D.P.; Mello, J.L.; Gorni, G.; Corbi, J.J. First report of Epibiont ciliates (Ciliophora: Peritrichia) living on larvae of Leptophlebiidae (Ephemeroptera) from Brazil. Braz. Arch. Biol. Technol. 2017, 60. [CrossRef]

90. Grzybkowska, M.; Szczerkowska-Majchrzak, E.; Dukowska, M.; Leszczynska, J.; Przybylski, M. Ephemera danica (Ephemeroptera: Ephemeridae) As a Resource for Two Commensals: Ciliated Protozoans (Sessilida) and Cironomids (Diptera). J. Insect Sci. 2016, 16, 67. [CrossRef] [PubMed]

91. Jacobsen, R.E. Symbiotic Associations between Chironomidae (Diptera) and Ephemeroptera. In Current Directions in Research on Ephemeroptera; Corkum, L.D., Ciborowski, J.J.H., Eds.; Canadian Scholars' Press Inc.: Toronto, ON, Canada, 1995; pp. 317-332.

92. Jacobsen, R.E. The symbiotic relationship of a chironomid with its ephemeropteran host in an Arizona mountain stream. J. Kansas Entomol. Soc. 1998, 71, 426-438.

93. Schiffels, S. Commensal and parasitic Chironomidae. Lauterbornia 2009, 68, 9-33.

94. Winterbourn, M.J. Association between a commensal chironomid and its mayfly host in rivers of North Westland. N. Z. Nat. Sci. 2004, 29, 21.

95. Moss, S.T. Harpellales (Trichomycetes); mycobionts of Insecta. Bot. J. Scotl. 1998, 50, 137-152. [CrossRef]

96. Valle, L.G.; Santamaria, S. Baetimyces, a new genus of Harpellales, and first report of Legeriomyces ramosus from the northeastern Iberian Peninsula. Mycologia 2002, 94, 321-326. [CrossRef]

97. Hirasawa, R.; Urabe, M. Ephemera strigata (Insecta: Ephemeroptera: Ephemeridae) is the intermediate host of the nematodes Rhabdochona denudata honshuensis and Rhabdochona coronacauda in Japan. J. Parasitol. 2003, 89, 285-293. [CrossRef]

98. Kageyama, D. Microbial Endosymbionts and Chemical Ecology. In Chemical Ecology of Insects; Tabata, J., Ed.; CRC Press: Boca Raton, FL, USA, 2018; pp. 114-130. 
99. Mariluan, G.D.; Viozzi, G.P.; Albariño, R.J. Trematodes and nematodes parasitizing the benthic insect community of an Andean Patagonian stream, with emphasis on plagiorchiid metacercariae. Invertebr. Biol. 2012, 131, 285-293. [CrossRef]

100. Poinar, G.; Walder, L.; Uno, H. Anomalomermis ephemerophagis ng, n. sp. (Nematoda: Mermithidae) parasitic in the mayfly Ephemerella maculata Traver (Ephermeroptera: Ephermerellidae) in California, USA. Syst. Parasitol. 2015, 90, 231-236. [CrossRef]

101. Reyes-Torres, L.J.; Meléndez-Torres, Y.; Ramirez, A. Occurrence of nematodes on Ephemeroptera nymphs in a tropical rainforest stream. Intropica 2016, 11, 67. [CrossRef]

102. Vance, S.A. Morphological and behavioural sex reversal in mermithid- infected mayflies. Proc. R. Soc. Lond. Ser. B-Biol. Sci. 1996, 263, 907-912.

103. Vance, S.A.; Peckarsky, B.L. The infection of nymphal Baetis bicaudatus by the mermithid nematode Gasteromermis sp. Ecol. Entomol. 1996, 21, 377-381. [CrossRef]

104. Vance, S.A.; Peckarsky, B.L. The effect of mermithid parasitism on predation of nymphal Baetis bicaudatus (Ephemeroptera) by invertebrates. Oecologia 1997, 110, 147-152. [CrossRef] [PubMed]

105. Heneberg, P.; Faltynkova, A.; Bizos, J.; Mala, M.; Ziak, J.; Literak, I. Intermediate hosts of the trematode Collyriclum faba (Plagiochiida: Collyriclidae) identified by an integrated morphological and genetic approach. Parasites Vectors 2015, 8. [CrossRef] [PubMed]

106. Gamboa, M.; Reyes, R.; Arrivillaga, J. Benthic macroinvertebrates as bioindicators of environmental health. Boletin de Malariologia y Salud Ambiental 2008, 48, 109-120.

107. Glazaczow, A.; Orwin, D.; Bajaczyk, R. The influence of river functionality on habitat selection by Ephemeroptera in spatially and temporally diverse lowland rivers, with particular reference to the River Bug. Oceanol. Hydrobiol. Stud. 2009, 38, 63-76. [CrossRef]

108. Hawkes, H.A. Origin and development of the Biological Monitoring Working Party score system. Water Res. 1998, 32, 964-968. [CrossRef]

109. Hilsenhoff, W.L. Using a Biotic Index to Evaluate Water Quality in Streams; Technical Bulletin; Department of Natural Resources: Madison, WI, USA, 1982; Volume 132, pp. 1-22.

110. Hilsenhoff, W.L. An improved biotic index of organic stream pollution. Gt. Lakes Entomol. 1987, 20, 31-39.

111. Hilsenhoff, W.L. Rapid field assessment of organic pollution with a family-level biotic index. J. N. Am. Benthol. Soc. 1988, 7, 65-68. [CrossRef]

112. Verneaux, J.; Tuffery, G. Une méthode zoologique pratique de détermination de la qualité biologique des eaux courantes. Annales Scientifiques de l'Université de Besançon 1967, 1967, 79-90.

113. Barber-James, H.M.; Pereira-da-Conçeicoa, L.L. Efficacy and deficiencies of rapid biomonitoring in biodiversity conservation: A case study in South Africa. Afr. J. Aquat. Sci. 2016, 41, 337-343. [CrossRef]

114. Bo, T.; Doretto, A.; Laini, A.; Bona, F.; Fenoglio, S. Biomonitoring with macroinvertebrate communities in Italy: What happened to our past and what is the future? J. Limnol. 2017, 76, 21-28. [CrossRef]

115. Cardoni, S.; Tenchini, R.; Ficulle, I.; Piredda, R.; Simeone, M.C.; Belfiore, C. DNA barcode assessment of Mediterranean mayflies (Ephemeroptera), benchmark data for a regional reference library for rapid biomonitoring of freshwaters. Biochem. Syst. Ecol. 2015, 62, 36-50. [CrossRef]

116. Ceneviva-Bastos, M.; Prates, D.B.; de Mei Romero, R.; Bispo, P.C.; Casatti, L. Trophic guilds of EPT (Ephemeroptera, Plecoptera, and Trichoptera) in three basins of the Brazilian Savanna. Limnol.-Ecol. Manag. Inland Waters 2017, 63, 11-17. [CrossRef]

117. Ferro, M.L.; Sites, R.W. The Ephemeroptera, Plecoptera, and Trichoptera of Missouri State Parks, with notes on biomonitoring, mesohabitat associations, and distribution. J. Kansas Entomol. Soc. 2007, 80, 105-129. [CrossRef]

118. Habib, S.; Yousuf, A.R. Freshwater Zoobenthic Species: Role in Biomonitoring and Ecological ProcessesA Review. Ann. Aquac. Res. 2016, 3, 1015.

119. Iyagbaye, L.; Iyagbaye, R.; Omoigberale, M. Mayflies (Order Ephemeroptera) Distribution as Indicators of the Water Quality Status of a Stretch of Ovia River (Iguoriakhi), Edo State, Southern Nigeria. Int. J. Innov. Res. Dev. 2017, 6, 88-92. [CrossRef]

120. Mathers, K.L.; Chadd, R.P.; Extence, C.A.; Rice, S.P.; Wood, P.J. The implications of an invasive species on the reliability of macroinvertebrate biomonitoring tools used in freshwater ecological assessments. Ecol. Indic. 2016, 63, 23-28. [CrossRef] 
121. Valente-Neto, F.; Rodrigues, M.E.; de Oliveira Roque, F. Selecting indicators based on biodiversity surrogacy and environmental response in a riverine network: Bringing operationality to biomonitoring. Ecol. Indic. 2018, 94, 198-206. [CrossRef]

122. Wibowo, D.N.; Setijanto, S.; Santoso, S. Benthic macroinvertebrate diversity as biomonitoring of organic pollutions of river ecosystems in Central Java, Indonesia. Biodivers. J. Biol. Divers. 2017, 18, 671-676. [CrossRef]

123. Finley, M.L.D.; Kidd, K.A.; Curry, R.A.; Lescord, G.L.; Clayden, M.G.; O’Driscoll, N.J. A Comparison of Mercury Biomagnification through Lacustrine Food Webs Supporting Brook Trout (Salvelinus fontinalis) and Other Salmonid Fishes. Front. Environ. Sci. 2016, 4, 23. [CrossRef]

124. Xie, L.; Funk, D.H.; Buchwalter, D.B. Trophic transfer of Cd from natural periphyton to the grazing mayfly Centroptilum triangulifer in a life cycle test. Environ. Pollut. 2010, 158, 272-277. [CrossRef] [PubMed]

125. Friberg, N.; Bonada, N.; Bradley, D.C.; Dunbar, M.J.; Edwards, F.K.; Grey, J.; Hayes, R.B.; Hildrew, A.G.; Lamouroux, N.; Trimmer, M.; et al. Biomonitoring of Human Impacts in Freshwater Ecosystems: The Good, the Bad and the Ugly. In Advances in Ecological Research; Woodward, G., Ed.; Academic Press: Amsterdam, The Netherlands, 2011; Volume 44, pp. 1-68.

126. Resh, V.H. Multinational, freshwater biomonitoring programs in the developing world: Lessons learned from African and Southeast Asian river surveys. Environ. Manag. 2007, 39, 737-748. [CrossRef] [PubMed]

127. Macadam, C.R. Freshwaters for the Future: A Strategy for Freshwater Invertebrates; Buglife-The Invertebrate Conservation Trust: Peterborough, UK, 2015.

128. Wallace, J.B.; Grubaugh, J.W.; Whiles, M.R. Biotic indices and stream ecosystem processes: Results from an experimental study. Ecol. Appl. 1996, 6, 140-151. [CrossRef]

129. Zedkova, B.; Radkova, V.; Bojkova, J.; Soldán, T.; Zahradkova, S. Mayflies (Ephemeroptera) as indicators of environmental changes in the past five decades: A case study from the Morava and Odra River Basins (Czech Republic). Aquat. Conserv.-Mar. Freshw. Ecosyst. 2015, 25, 622-638. [CrossRef]

130. Svensson, A.; Bellamy, A.S.; Van den Brinck, P.J.; Tedengren, M.; Gunnarsson, J.S. Assessing the ecological impact of banana farms on water quality using aquatic macroinvertebrate community composition. Environ. Sci. Pollut. Res. 2018, 25, 13373-13381. [CrossRef] [PubMed]

131. Dahl, J.; Johnson, R.K.; Sandin, L. Detection of organic pollution of streams in southern Sweden using benthic macroinvertebrates. In Integrated Assessment of Running Waters in Europe; Hering, D., Verdonschot, P., Moog, O., Sandin, L., Eds.; Springer: Dordrecht, The Netherlands, 2004; pp. 161-172.

132. Parr, T.B.; Cronan, C.S.; Danielson, T.J.; Tsomides, L.; Simon, K.S. Aligning indicators of community composition and biogeochemical function in stream monitoring and ecological assessments. Ecol. Indic. 2016, 60, 970-979. [CrossRef]

133. Timm, H.; Ivask, M.; Möls, T. Response of macroinvertebrates and water quality to long-term decrease in organic pollution in some Estonian streams during 1990-1998. Hydrobiologia 2001, 464, 153-164. [CrossRef]

134. Menetrey, N.; Oertli, B.; Sartori, M.; Wagner, A.; Lachavanne, J.B. Eutrophication: Are mayflies (Ephemeroptera) good bioindicators for ponds? Hydrobiologia 2008, 597, 125-135. [CrossRef]

135. Sandin, L.; Johnson, R.K. The statistical power of selected indicator metrics using macroinvertebrates for assessing acidification and eutrophication of running waters. In Assessing the Ecological Integrity of Running Waters; Jungwirth, M., Muha, S., Schmutz, S., Eds.; Springer: Dordrecht, The Netherlands, 2000; pp. 233-243.

136. Extence, C.A.; Balbi, D.M.; Chadd, R.P. River flow indexing using British benthic macroinvertebrates: A framework for setting hydroecological objectives. Regul. Rivers Res. Manag. 1999, 15, 543-574. [CrossRef]

137. Davy-Bowker, J.; Murphy, J.F.; Rutt, G.P.; Steel, J.E.C.; Furse, M.T. The development and testing of a macroinvertebrate biotic index for detecting the impact of acidity on streams. Archiv für Hydrobiologie 2005, 163, 383-403. [CrossRef]

138. Macedo-Sousa, J.A.; Gerhardt, A.; Brett, C.M.; Nogueira, A.J.; Soares, A.M. Behavioural responses of indigenous benthic invertebrates (Echinogammarus meridionalis, Hydropsyche pellucidula and Choroterpes picteti) to a pulse of acid mine drainage: A laboratorial study. Environ. Pollut. 2008, 156, 966-973. [CrossRef] [PubMed]

139. Chadd, R.P.; England, J.A.; Constable, D.; Dunbar, M.J.; Extence, C.A.; Leeming, D.J.; Murray-Bligh, J.A.; Wood, P.J. An index to track the ecological effects of drought development and recovery on riverine invertebrate communities. Ecol. Indic. 2017, 82, 344-356. [CrossRef] 
140. Extence, C.A.; Chadd, R.P.; England, J.; Dunbar, M.J.; Wood, P.J.; Taylor, E.D. The assessment of fine sediment accumulation in rivers using macro-invertebrate community response. River Res. Appl. 2013, 29, 17-55. [CrossRef]

141. Schriever, C.A.; Hansler-Ball, M.; Holmes, C.; Maund, S.; Liess, M. Agricultural intensity and landscape structure: Influences on the macroinvertebrate assemblages of small streams in northern Germany. Environ. Toxicol. Chem. 2007, 26, 346-357. [CrossRef] [PubMed]

142. Hilsenhoff, W.L. Changes in the downstream insect and amphipod fauna caused by an impoundment with a hypolimnion drain. Ann. Entomol. Soc. Am. 1971, 64, 743-746. [CrossRef]

143. Liarte, S.; Ubero-Pascal, N.; Garcia-Ayala, A.; Puig, M.A. Histological effects and localization of dissolved microcystins LR and LW in the mayfly Ecdyonurus angelieri Thomas (Insecta, Ephemeroptera). Toxicon 2014, 92,31-35. [CrossRef] [PubMed]

144. Conti, L.; Schmidt-Kloiber, A.; Grenouillet, G.; Graf, W. A trait-based approach to assess the vulnerability of European aquatic insects to climate change. Hydrobiologia 2014, 721, 297-315. [CrossRef]

145. Hershkovitz, Y.; Dahm, V.; Lorenz, A.W.; Hering, D. A multi-trait approach for the identification and protection of European freshwater species that are potentially vulnerable to the impacts of climate change. Ecol. Indic. 2015, 50, 150-160. [CrossRef]

146. Sandin, L.; Schmidt-Kloiber, A.; Svenning, J.-C.; Jeppesen, E.; Friberg, N. A trait-based approach to assess climate change sensitivity of freshwater invertebrates across Swedish ecoregions. Curr. Zool. 2014, 60, 221-232. [CrossRef]

147. Chacon, M.M.; Segnini, S.; Briceño, D. Temperature and daily emergence of seven genera of Ephemeroptera (Insecta) in a cloud forest stream of tropical Andes. Rev. Biol. Trop. 2016, 64, 117-130. [CrossRef] [PubMed]

148. Haidekker, A.; Hering, D. Relationship between benthic insects (Ephemeroptera, Plecoptera, Coleoptera, Trichoptera) and temperature in small and medium-sized streams in Germany: A multivariate study. Aquat. Ecol. 2008, 42, 463-481. [CrossRef]

149. Hwang, J.M.; Lee, S.J.; Bae, Y.J. Larval growth of Cloeon dipterum (Ephemeroptera: Baetidae) in different temperature conditions. Korean J. Environ. Biol. 2005, 23, 114-119. (In Korean)

150. Parnrong, S.; Campbell, I.C. The effects of temperature on egg hatching of the mayfly Austrophlebioides marchanti (Ephemeroptera: Leptophlebiidae). In Research Update on Ephemeroptera and Plecoptera; Gaino, E., Ed.; University of Perugia: Perugia, Italy, 2003; pp. 189-193.

151. Puckett, R.T.; Cook, J.L. Physiological tolerance ranges of larval Caenis latipennis (Ephemeroptera: Caenidae) in response to fluctuations in dissolved oxygen concentration, $\mathrm{pH}$ and temperature. Tex. J. Sci. 2004, 56, 123-130.

152. Ross-Gillespie, V.; Picker, M.D.; Dallas, H.F.; Day, J.A. The role of temperature in egg development of three aquatic insects Lestagella penicillata (Ephemeroptera), Aphanicercella scutata (Plecoptera), Chimarra ambulans (Trichoptera) from South Africa. J. Therm. Biol. 2018, 71, 158-170. [CrossRef] [PubMed]

153. Scherr, M.A.; Wooster, D.E.; Rao, S. Effects of Temperature on Growth Rate and Behavior of Epeorus albertae (Ephemeroptera: Heptageniidae) Nymphs. Environ. Entomol. 2011, 39, 2017-2024. [CrossRef] [PubMed]

154. Sweeney, B.W.; Funk, D.H.; Camp, A.A.; Buchwalter, D.B.; Jackson, J.K. Why adult mayflies of Cloeon dipterum (Ephemeroptera: Baetidae) become smaller as temperature warms. Freshw. Sci. 2018, 37, 64-81. [CrossRef]

155. Mo, H.H.; Lee, S.E.; Son, J.; Hwang, J.M.; Bae, Y.J.; Cho, K. Exposure of mayfly Ephemera orientalis (Ephemeroptera) eggs to heavy metals and discovery of biomarkers. Environ. Toxicol. Pharmacol. 2013, 36, 1167-1175. [CrossRef]

156. Haro, R.J.; Bailey, S.W.; Northwick, R.M.; Rolfhus, K.R.; Sandheinrich, M.B.; Wiener, J.G. Burrowing dragonfly larvae as biosentinels of methylmercury in freshwater food webs. Environ. Sci. Technol. 2013, 47, 8148-8156. [CrossRef]

157. Jardine, T.D.; Al, T.A.; MacQuarrie, K.T.; Ritchie, C.D.; Arp, P.A.; Maprani, A.; Cunjak, R.A. Water striders (family Gerridae): Mercury sentinels in small freshwater ecosystems. Environ. Pollut. 2005, 134, 165-171. [CrossRef]

158. Jardine, T.D.; Kidd, K.A.; Cunjak, R.A.; Arp, P.A. Factors affecting water strider (Hemiptera: Gerridae) mercury concentrations in lotic systems. Environ. Toxicol. Chem. 2009, 28, 1480-1492. [CrossRef] [PubMed]

159. Conley, J.M.; Funk, D.H.; Hesterberg, D.H.; Hsu, L.C.; Kan, J.; Liu, Y.T.; Buchwalter, D.B. Bioconcentration and biotransformation of selenite versus selenate exposed periphyton and subsequent toxicity to the mayfly Centroptilum triangulifer. Environ. Sci. Technol. 2013, 47, 7965-7973. [CrossRef] [PubMed] 
160. Lagauzère, S.; Boyer, P.; Stora, G.; Bonzon, J.M. Effects of uranium-contaminated sediments on the bioturbation activity of Chironomus riparius larvae (Insecta, Diptera) and Tubifex tubifex worms (Annelida, Tubificidae). Chemosphere 2009, 76, 324-334. [CrossRef] [PubMed]

161. Beketov, M. Different sensitivity of mayflies (Insecta, Ephemeroptera) to ammonia, nitrite and nitrate: Linkage between experimental and observational data. Hydrobiologia 2004, 528, 209-216. [CrossRef]

162. Marie, V.; Dia, A.; Thomas, A. Compléments et corrections à la faune des Ephéméroptères du Proche-Orient. 3. Serratella bauernfeindi n.sp. du Liban: Description comparativement à S. mesoleuca (Brauer, 1857) et écologie (Ephemeroptera, Ephemerellidae). Ephemera 2000, 1, 93-103, (1999).

163. Vidinova, Y.; Russev, B.K. Distribution and ecology of the representatives of some Ephemeropteran families in Bulgaria. In Ephemeroptera E Plecoptera Biology-Ecology-Systematics; Landolt, P., Sartori, M., Eds.; Mauron+Tinguely \& Lachat SA: Fribourg, Switzerland, 1997; pp. 139-146.

164. Back, J.A.; Taylor, J.M.; King, R.S.; Fallert, K.L.; Hintzen, E.H. Ontogenic differences in mayfly stoichiometry influence growth rates in response to phosphorus enrichment. Fundam. Appl. Limnol. 2008, 171, 233-240. [CrossRef]

165. Lemly, A.D.; King, R.S. An insect-bacteria bioindicator for assessing detrimental nutrient enrichment in wetlands. Wetlands 2000, 20,91-100. [CrossRef]

166. Peterson, R.H.; Gordon, D.J.; Johnston, D.J. Distribution of mayfly nymphs (Insecta: Ephemeroptera) in some streams of eastern Canada as related to stream pH. Can. Field-Nat. 1985, 99, 490-493.

167. Feldman, R.S.; Connor, E.F. The relationship between $\mathrm{pH}$ and community structure of invertebrates in streams of the Shenandoah National Park, Virginia, U.S.A. Freshw. Biol. 1992, 27, 261-276. [CrossRef]

168. WWF. Living Planet Report-2018: Aiming Higher; Grooten, M., Almond, R.E.A., Eds.; WWF: Gland, Switzerland, 2018.

169. Hallmann, C.A.; Sorg, M.; Jongejans, E.; Siepel, H.; Hofland, N.; Schwan, H.; Stenmans, W.; Müller, A.; Sumser, H.; Hörren, T.; et al. More than 75 percent decline over 27 years in total flying insect biomass in protected areas. PLoS ONE 2017, 12, e0185809. [CrossRef]

170. Frake, A.; Hayes, P. Report on the Millennium Chalk Streams Fly Trends Study; Environment Agency: Exeter, UK, 2001.

171. UICN. IUCN Red List Categories and Criteria. Version 3.1, 2nd ed.; IUCN Species Survival Commission: Gland, Switzerland; Cambridge, MA, USA, 2012; p. 32.

172. Collen, B.; Böhm, M.; Kemp, R.; Baillie, J.E.M. Spineless: Status and Trends of the World's Invertebrates; Zoological Society of London: London, UK, 2012.

173. Wagner, A.; Sartori, M. Liste rouge des Ephémères de Suisse. In Listes rouges Ephémères, Plécoptères Trichoptères: Espèces Menacées en Suisse, état 2010; Lubini, V., Knispel, S., Sartori, M., Vicentini, F.L., Wagner, A., Eds.; Centre Suisse de Cartographie de la Faune: Bern, Switzerland, 2012.

174. UICN France; MNHN; Opie. La Liste Rouge des Espèces Menacées en France-Chapitre Ephémères de France Métropolitaine; UICN: Paris, France, 2018; p. 4.

175. Jacobus, L.M. South Carolina mayflies (Insecta: Ephemeroptera) of conservation concern. J. S. C. Acad. Sci. 2013, 11, 23-26.

176. Hudson, L.A.; Ciborowski, J.J.H. Spatial and taxonomic variation in incidence of mouthpart deformities in midge larvae (Diptera: Chironomidae: Chironomini). Can. J. Fish. Aquat. Sci. 1996, 53, 297-304. [CrossRef]

177. Everall, N.C.; Johnson, M.F.; Wood, P.J.; Mattingley, L. Sensitivity of the early life stages of a mayfly to fine sediment and orthophosphate levels. Environ. Pollut. 2018, 237, 792-802. [CrossRef] [PubMed]

178. Larsen, S.; Pace, G.; Ormerod, S. Experimental effects of sediment deposition on the structure and function of macroinvertebrate assemblages in temperate streams. River Res. Appl. 2011, 27, 257-267. [CrossRef]

179. Larsen, S.; Ormerod, S. Combined effects of habitat modification on trait composition and species nestedness in river invertebrates. Biol. Conserv. 2010, 143, 2638-2646. [CrossRef]

180. Angradi, T.R. Fine sediment and macroinvertebrate assemblages in Appalachian streams: A fields experiment with biomonitoring applications. J. N. Am. Benthol. Soc. 1999, 18, 49-66. [CrossRef]

181. Matthaei, C.D.; Weller, F.; Kelly, D.W.; Townsend, C.R. Impacts of fine sediment addition to tussock, pasture, dairy and deer farming streams in New Zealand. Freshw. Biol. 2006, 51, 2154-2172. [CrossRef]

182. Opfer, S.E.; Farver, J.R.; Miner, J.G.; Krieger, K. Heavy metals in sediments and uptake by burrowing mayflies in western Lake Erie basin. J. Gt. Lakes Res. 2011, 37, 1-8. [CrossRef] 
183. Wesner, J.S.; Walters, D.M.; Schmidt, T.S.; Kraus, J.M.; Stricker, C.A.; Clements, W.H.; Wolf, R.E. Metamorphosis affects metal concentrations and isotopic signatures in a mayfly (Baetis tricaudatus): Implications for the aquatic-terrestrial transfer of metals. Environ. Sci. Technol. 2017, 51, 2438-2446. [CrossRef]

184. Malaj, E.; von der Ohe, P.C.; Grote, M.; Kühne, R.; Mondy, C.P.; Usseglio-Polatera, P.; Brack, W.; Schäfer, R.B. Organic chemicals jeopardize the health of freshwater ecosystems on the continental scale. Proc. Natl. Acad. Sci. USA 2014, 111, 9549-9554. [CrossRef]

185. Raby, M.; Nowierski, M.; Perlov, D.; Zhao, X.; Hao, C.; Poirier, D.G.; Sibley, P.K. Acute toxicity of 6 neonicotinoid insecticides to freshwater invertebrates. Environ. Toxicol. Chem. 2018, 37, 1430-1445. [CrossRef] [PubMed]

186. Van den Brinck, P.J.; Van Smeden, J.M.; Bekele, R.S.; Dierick, W.; De Gelder, D.M.; Noteboom, M.; Roessink, I. Acute and chronic toxicity of neonicotinoids to nymphs of a mayfly species and some notes on seasonal differences. Environ. Toxicol. Chem. 2016, 35, 128-133. [CrossRef] [PubMed]

187. Van Dijk, T.C.; Van Staalduinen, M.A.; Van der Sluijs, J.P. Macro-Invertebrate Decline in Surface Water Polluted with Imidacloprid. PLoS ONE 2013, 8, e62374. [CrossRef] [PubMed]

188. Morrissey, C.A.; Mineau, P.; Devries, J.H.; Sanchez-Bayo, F.; Liess, M.; Cavallaro, M.C.; Liber, K. Neonicotinoid contamination of global surface waters and associated risk to aquatic invertebrates: A review. Environ. Int. 2015, 74, 291-303. [CrossRef] [PubMed]

189. Roessink, I.; Merga, L.B.; Zweers, H.J.; Van den Brinck, P.J. The neonicotinoid Imidacloprid shows high chronic toxicity to mayfly nymphs. Environ. Toxicol. Chem. 2013, 32, 1096-1100. [CrossRef] [PubMed]

190. Shardlow, M. Neonicotinoid Insecticides in British Freshwaters; Buglife-The Invertebrate Conservation Trust: Petersborough, UK, 2017; p. 62.

191. Richmond, E.K.; Rosi, E.J.; Walters, D.M.; Fick, J.; Hamilton, S.K.; Brodin, T.; Sundelin, A.; Grace, M.R. A diverse suite of pharmaceuticals contaminates stream and riparian food webs. Nat. Commun. 2018, 9, 4491. [CrossRef] [PubMed]

192. Iwasaki, Y.; Kagaya, T.; Matsuda, H. Comparing macroinvertebrate assemblages at organic-contaminated river sites with different zinc concentrations: Metal-sensitive taxa may already be absent. Environ. Pollut. 2018, 241, 272-278. [CrossRef] [PubMed]

193. Gallardo, B.; Aldridge, D. Review of the Ecological Impact and Invasion Potential of Ponto Caspian Invaders in Great Britain; Cambridge Environmental Consulting: Cambridge, UK, 2013; p. 130.

194. Lowe, S.; Browne, M.; Boudjelas, S.; De Poorter, M. 100 of the World's Worst Invasive Alien Species A Selection from the Global Invasive Species Database; IUCN: Gland, Switzerland, 2000; p. 12.

195. Kettunen, M.; Genovesi, P.; Gollasch, S.; Pagad, S.; Starfinger, U.; ten Brink, P.; Shine, C. Technical Support to EU Strategy on Invasive Species (IAS)_Assessment of the Impacts of IAS in Europe and the EU (Final Module Report for the European Commission); Institute for European Environmental Policy (IEEP): Brussels, Belgium, 2008; p. $44+$ Appendices.

196. Palmer, M.; Macadam, C.R. Developing a Priority List of Alien Invasive Invertebrate Species; Buglife: Petersborough, UK, 2014.

197. Tricarico, H.; Junqueira, A.O.R.; Dudgeon, D.D. Alien species in aquatic environments: A selective comparison of coastal and inland waters in tropical and temperate latitudes. Aquat. Conserv.-Mar. Freshw. Ecosyst. 2016, 26, 872-891. [CrossRef]

198. Carpenter, S.R.; Stanley, E.H.; Vander Zanden, M.J. State of the World's freshwater ecosystems: Physical, chemical, and biological changes. Ann. Rev. Environ. Res. 2011, 36, 75-99. [CrossRef]

199. Zarfl, C.; Lumsdon, A.E.; Berlekamp, J.; Tydecks, L.; Tockner, K. A global boom in hydropower dam construction. Aquat. Sci. 2015, 77, 161-170. [CrossRef]

200. Souto, P.M.; Angeli, K.B.; Salles, F.F. Tricorythodes tragoedia sp nov (Ephemeroptera: Leptohyphidae), a new species from Rio Doce and surrounding areas, southeastern Brazil. Zootaxa 2017, 4341, 554-562. [CrossRef] [PubMed]

201. Kennedy, T.A.; Muehlbauer, J.D.; Yackulic, C.B.; Lytle, D.A.; Miller, S.W.; Dibble, K.L.; Kortenhoeven, E.W.; Metcalfe, A.N.; Baxter, C.V. Flow Management for Hydropower Extirpates Aquatic Insects, Undermining River Food Webs. Bioscience 2016, 66, 561-575. [CrossRef] 
202. Manfrin, A.; Singer, G.; Larsen, S.; Weiß, N.; van Grunsven, R.H.A.; Weiß, N.-S.; Wohlfahrt, S.; Monaghan, M.T.; Hölker, F. Artificial light at night affects organism flux across ecosystem boundaries and drives community structure in the recipient ecosystem. Front. Environ. Sci. 2017, 5, 61. [CrossRef]

203. Kriska, G.; Horvath, G.; Andrikovics, S. Why do mayflies lay their eggs "en masse" on dry asphalts roads? Water-immitating polarized light reflected from asphalt attracts Ephemeroptera. J. Exp. Biol. 1998, 201, 2273-2286. [PubMed]

204. Horvath, G.; Kriska, G. Polarization vision in aquatic insects and ecological traps for polarotactic insects. In Aquatic Insects: Challenges to Populations; Lancaster, J., Briers, B.A., Eds.; CAB International Publishing: Wallingford, UK, 2008; pp. 204-229.

205. Horvath, G.; Blaho, M.; Egri, A.; Kriska, G.; Seres, I.; Robertson, B. Reducing the Maladaptive Attractiveness of Solar Panels to Polarotactic Insects. Conserv. Biol. 2010, 24, 1644-1653. [CrossRef] [PubMed]

206. Loxdale, H.; Loxdale, N.; Macadam, C.R. A bridge too far... at least for caddisflies and Mayflies. Antenna 2013, 37, 106-110.

207. Malnas, K.; Polyak, L.; Prill, E.; Hegedus, R.; Kriska, G.; Devai, G.; Horvath, G.; Lengyel, S. Bridges as optical barriers and population disruptors for the mayfly Palingenia longicauda: An overlooked threat to freshwater biodiversity? J. Insect Conserv. 2011, 15, 823-832. [CrossRef]

208. Cañedo-Argüelles, M.; Kefford, B.J.; Piscart, C.; Prat, N.; Schäfer, R.B.; Schulz, C.J. Salinisation of rivers: An urgent ecological issue. Environ. Pollut. 2013, 173, 157-167. [CrossRef]

209. Center, S.W.R. Ecotoxicity Study for Mayflies Exposed to Ambient Stream Water from the Upper Delaware River Basin, Reference Toxicant, and to Produced-Water from Natural Gas Drilling; Publication Number 2013003; Stroud Water Research Center: Avondale, PA, USA, 2013.

210. Hannah, L. Climate Change Biology, 2nd ed.; Academic Press: New York, NY, USA, 2014.

211. Brittain, J.E. Mayflies, biodiversity and climate change. In International Advances in the Ecology, Zoogeography and Systematics of Mayflies and Stoneflies; Hauer, F.R., Stanford, J.A., Newell, R.L., Eds.; University of California Press: Berkeley, CA, USA, 2008; pp. 1-14.

212. Darwall, W.; Bremerich, V.; De Wever, A.; Dell, A.I.; Freyhof, J.; Gessner, M.O.; Grossart, H.P.; Harrison, I.; Irvine, K.; Jahnig, S.C.; et al. The Alliance for Freshwater Life: A global call to unite efforts for freshwater biodiversity science and conservation. Aquat. Conserv.-Mar. Freshw. Ecosyst. 2018, 28, 1015-1022. [CrossRef]

213. Hering, D.; Schmidt-Kloiber, A.; Murphy, J.; Locke, S.; Zamora-Muñoz, C.; Lopez Rodriguez, M.J.; Huber, T.; Graf, W. Potential impact of climate change on aquatic insects: A sensitivity analysis for European caddisflies (Trichoptera) based on distribution patterns and ecological preferences. Aquat. Sci. 2009, 71, 3-14. [CrossRef]

214. Durance, I.; Ormerod, S. Climate change effects on upland stream macroinvertebrates over a 25-year period. Glob. Chang. Biol. 2007, 13, 942-957. [CrossRef]

215. Kitchen, L.; Macadam, C.R.; Yeomans, W.E. Is the Upland Summer Mayfly (Ameletus Inopinatus Eaton 1887) in Hot Water? Freshwater Biological Association: Windermere, UK, 2010.

216. Taubmann, J.; Theissinger, K.; Feldheim, K.A.; Laube, I.; Graf, W.; Haase, P.; Johannesen, J.; Pauls, S.U. Modelling range shifts and assessing genetic diversity distribution of the montane aquatic mayfly Ameletus inopinatus in Europe under climate change scenarios. Conserv. Genet. 2011, 12, 503-515. [CrossRef]

217. Jonsson, M.; Hedström, P.; Stenroth, K.; Hotchkiss, E.R.; Vasconcelos, F.R.; Karlsson, J.; Byström, P. Climate change modifies the size structure of assemblages of emerging aquatic insects. Freshw. Biol. 2015, 60, 78-88. [CrossRef]

(C) 2019 by the authors. Licensee MDPI, Basel, Switzerland. This article is an open access article distributed under the terms and conditions of the Creative Commons Attribution (CC BY) license (http://creativecommons.org/licenses/by/4.0/). 